\title{
STARTING TO SHINE, BUT HOW BRIGHTLY? STANDSTILL PROVISIONS IN ASSOCIATION LAW BETWEEN TURKEY AND THE COMMUNITY
}

\begin{abstract}
Ilke Göçmen*
Summary: Today, it is known that the association law between Turkey and the Community grants rights to Turkish citizens which are legally enforceable before the national authorities and courts of the Member States, thanks to the decisions of the Court of Justice. Recent years have witnessed a number of cases before the Court regarding the standstill provisions in association law relating to workers on the one hand and freedom of establishment and to provide services on the other. One striking example is the Soysal case, which paved the way for certain Turkish nationals to travel to Germany without a visa. Therefore, there is a strong need to explore the exact boundaries of the abovementioned standstill clauses. This paper examines the nature, scope and effects of these standstill provisions.
\end{abstract}

\section{Introduction}

The association law between Turkey and the Community grants rights to Turkish citizens which are legally enforceable before the national authorities and courts of the Member States, thanks to the decisions of the Court of Justice. In recent years, a new wave of cases has broken on the shores of the legal orders of the Member States and EC. These are related to the standstill provision relating to the freedom of establishment and to provide services.

A standstill clause is a provision in an agreement that forbids a party from changing conditions from how they stand at the time of entry into force of the agreement to the detriment of the applicant. ${ }^{1}$ Hence, they cannot be regarded as substantive rules which take the place of inconsistent rules, since they only refer to the legislation of a certain time that applies in a concrete situation.

\footnotetext{
* Research Assistant at the Faculty of Law of the University of Ankara. I am deeply grateful to AJT Woltjer for his valuable comments.

1 N Rogers, A Practitioners' Guide to the EC-Turkey Association Agreement (Kluwer Law International, Great Britain 2000) 27. Guild finds the effect of the standstill provisions curious, since they freeze the situation in national law by the application of Community law but in no way affect the validity of national law. E Guild, Immigration Law in the European Community (Kluwer Law International, the Netherlands 2001) 135.
} 
There are two standstill clauses in association law: one relates to workers and the other concerns the freedom of establishment and to provide services. Both of these have a direct effect in Community law. They have the same meaning, ${ }^{2}$ although each of them has been given a very specific scope. They therefore cannot be applied concurrently. ${ }^{3}$ For this reason, their scope of application gains importance.

This article will try to analyse standstill provisions in association law. To achieve this aim, this article is divided into three sections. The first section deals with preliminary issues regarding Turkish-Community relations in general and association law in particular. The second and third sections are dedicated to the standstill provisions, the first relating to workers and the other regarding the freedom of establishment and to provide services. In both of these sections, I will attempt to clarify the scope and effects of these provisions.

\section{General remarks on Turkish-Community relations and association law}

This section contains general remarks on the relationship between Turkey and the Community/Union and on association law. This is necessary before we can deal with the standstill clauses set out in association law.

\section{Two different models of relationship}

The relationship between Turkey and the Community/Union has two dimensions: association and membership. ${ }^{4}$

\section{A. Association}

The association relationship goes back to 1959 to the time shortly after the foundation of the Community in $1958 .{ }^{5}$ It was 31 July 1959

\footnotetext{
2 Joined Cases C-317/01 and 369/01 Eran Abatay and Others and Nadi Sahin v Bundesanstalt für Arbeit [2003] ECR I-12301 paras 70-71.

3 Abatay and Sahin (n 2) para 86.

4 For detailed information on both of these subjects, see T Arat, and C Erhan, 'AETyle Illişkiler' in B Oran (ed), Türk Dış Politikast: Cilt I: 1919-1980 (12 $2^{\text {th }}$ edn İletișim Yayınları, İstanbul 2006) 808-853; T Arat and Ç Erhan, 'ATyle İlişkiler' in B Oran (ed), Türk Dış Politikası: Cilt II: 1980-2001 (9 $9^{\text {th }}$ edn İletişim Yayınları, İstanbul 2006) 83-101; T Arat and S Baykal, 'AB'yle İlişkiler' in B Oran (ed), Türk Diş Politikası: Cilt II: 1980-2001 (9 ${ }^{\text {th }}$ edn İletissim Yayınları, İstanbul 2006) 326-365.

5 The Community was found by TEEC, which entered into force on 1 January 1958. TEEC is not published in the Official Journal.
} 
when Turkey applied to begin an association relationship. ${ }^{6}$ The EEC welcomed Turkey and the relationship model was based on Article 238 of the Treaty Establishing the European Economic Community (TEEC), which regulates association. It took four years for the parties (Turkey on the one hand and the EEC and the then Member States on the other) to agree upon an Association Agreement (the Ankara Agreement). ${ }^{7}$ This was signed on 12 September 1963 and entered into force on 1 December $1964 .^{8}$

The Ankara Agreement, which established the basis of the association relationship, was just the beginning. To strengthen the relationship, the instruments offered by the Agreement were twofold. The first, with which lawyers are familiar, was the ordinary method of laying down rules at the international level: international agreements. ${ }^{9}$ The second, which was something of an innovation, was to create an institution (the Association Council) with decision-making powers in the areas covered by the association: Association Council Decisions (ACDs). ${ }^{10}$

It was now time to construct an association consisting of three phases: a preparatory stage, a transitional stage and a final stage. Although the preparatory stage was regulated in the Ankara Agreement, ${ }^{11}$ an international agreement was required to change over to the transitional stage. ${ }^{12}$ This led to the Additional Protocol (AP), which was signed on 23

6 See H Can and Ç Özen, Türkiye-Avrupa Topluluğu Ortaklık Hukuku (Gazi Kitabevi, Ankara 2005) 1; H Günuğur, Türkiye-Avrupa Birliği İlişkileri (Avrupa Ekonomik Danışma Merkezi, Ankara 2008) 8; E Lenski, 'Turkey and the EU: On the Road to Nowhere?' (2003) 63 (1) Zeitschrift für Ausländisches Öffentliches Recht und Völkerrecht 78. Some authors, on the contrary, state that Turkey knocked on the door of the Community in order to join the club. N Rogers and R Scannel, Free Movement of Persons in the Enlarged European Union (Sweet \& Maxwell, London 2005) 325. For the reasons why Turkey applied to the Community, see Can and Özen (n 6) 1-8; Günuğur (n 6) 4-7.

7 For details of the negotiations on the Ankara Agreement, see Can and Özen (n 6) 9-17; Günuğur (n 6) 8-17.

8 For Turkey, Official Gazette, no 11858, 17 November 1964. For the EEC, The Agreement establishing an Association between the European Economic Community and Turkey, signed in Ankara on 12 September 1963 by the Republic of Turkey and by the Member States of the EEC and the Community, and concluded, approved and confirmed on behalf of the Community by Council Decision 64/732/EEC of 23 December 1963 [1973] OJ C 113,1 .

9 See Article 90 of the Turkish Constitution (its heading is "Ratification of International Treaties') (Article 90 of the Turkish Constitution dated 1982 was written identically to Article 65 of the Turkish Constitution dated 1961.) See also arts 310 and 300 of the Treaty Establishing the European Community (TEC) (arts 228 and 238 TEEC).

10 Arts 6, 22-25, 27-28 Ankara Agreement.

11 Art 3 Ankara Agreement.

12 Arts 3, 4, 8 Ankara Agreement and art 1 Provisional Protocol attached to the Ankara Agreement. 
November 1970 and entered into force in $1973 .{ }^{13}$ This opened the way to a further strengthening of the association process.

Despite the provisions required for the integration process, neither economic nor political conditions went smoothly in the 1970s and 1980s. ${ }^{14}$ However, during this period, there were at least some decisions of the Association Council that led to detailed provisions in certain areas of the association. For the purposes of this study, ACD 2/76 and 1/80, which have provisions relating to workers, will be emphasised.

The resurrection of the association coincided with the membership application of Turkey to the EEC in 1987. During the late 1980s and the first half of the 1990s, Turkey intensified its efforts to catch up with its obligations of association. ${ }^{15}$ In the end, the way to the beginning of the final stage was paved and Turkey and the EC established a customs union, which was accomplished officially by ACD 1/95. This decision was adopted on 6 March 1995 and entered into force on 31 December 1995. ${ }^{16}$

Besides being a candidate country, Turkey is still in an association relationship with the EC. Being in the final stage of the association, the parties are under an obligation to ensure closer co-ordination of their economic policies. ${ }^{17}$ However, the focus of the parties has been shifted from an association to membership relationship, especially during the second half of the 1990s.

\section{B. Membership}

This long-lasting and still ongoing process started on 14 April 1987 when Turkey applied officially for membership to the Communities. ${ }^{18}$ Turkey would have to wait for two years for an Opinion of the Commission about this application, which came on 20 December 1989. ${ }^{19}$ Accord-

13 For Turkey, Official Gazette, no 13675, 22 November 1970. For the EEC, Additional Protocol signed on 23 November 1970, annexed to the Agreement establishing an association between the European Economic Community and Turkey, concluded by Regulation (EEC) No 2760/72 of the Council of 19 December 1972 [1972] OJ L 293, 1. For details of the negotiations on the Additional Protocol, see Can and Özen (n 6) 31-38.

14 See Can and Özen (n 6) 62-66.

15 See Can and Özen (n 6) 67-71.

16 Decision No 1/95 of the EC-Turkey Association Council of 22 December 1995 on implementing the final phase of the Customs Union [1996] OJ L 35, 1.

17 Art 5 Ankara Agreement.

18 The application was pursuant to Article 237 of the TEEC, Article 205 of the European Atomic Energy Community (EURATOM) and Article 98 of the Treaty Establishing the European Coal and Steel Community (TECSC).

19 Commission (EC) 'Opinion on Turkey's Request for Accession to the Community' (Opinion) SEC (89) 2290 final/2, 20 December 1989. 
ing to this Opinion, though Turkey was eligible for full membership, the time was still too early because of the internal market processes of the Community and the economic, social and political situation in Turkey. The Council of Ministers approved the Opinion of the Commission in February 1990.

On receiving this negative answer, Turkey concentrated on association relations and as mentioned above, a customs union was realised as of 1 January 1996. In the view of Turkey, the next step was to be regarded as a candidate country. However, the European Council which met in Luxembourg on 12-13 December 1997 did not even mention Turkey as one of the candidate countries. As a reaction to this decision, Turkey took the decision to freeze political dialogue with the EU. ${ }^{20}$ However, the following year (1998) the Commission prepared its first progress report, which has been prepared once a year by the Commission ever since.

Waiting twelve years for the word, Turkey was given 'candidate' status by the European Council which met in Helsinki on 11-12 December 1999. Although negotiations did not begin immediately, the candidacy process had been started. The Council of Ministers accepted the Accession Partnership Document for Turkey on 8 March 2001. ${ }^{21}$ Shortly afterwards, on 19 March 2001, Turkey submitted its National Programme for the adoption of the acquis communautaire. ${ }^{22}$

Turkey was now waiting for negotiations to begin. However, the European Council which met in Copenhagen on 12-13 December 2002 left the task of deciding whether to begin negotiations for the summit of December 2004. Although the summit was waited for with enthusiasm, the candidacy was already on the move. The Council of Ministers agreed to the revised Accession Partnership Document for Turkey on 8 March $2003,{ }^{23}$ and Turkey, on 24 July 2003, accepted the revised National Programme for the adoption of the acquis communautaire. ${ }^{24}$

Finally, negotiations were on the table and the European Council which met in Copenhagen on 17 December 2004 stated that negotiations with Turkey would begin on 3 October 2005. On that date, the Council of Ministers adopted the Negotiating Framework and the negotiation proc-

\footnotetext{
20 See Günuğur (n 6) 157.

21 Council Decision 2001/235/EC of 8 March 2001 on the principles, priorities, intermediate objectives and conditions contained in the Accession Partnership with the Republic of Turkey [2001] OJ L 85, 13.

22 Official Gazette no 24352 bis, 24 March 2001.

23 Council Decision 2003/398/EC of 19 May 2003 on the principles, priorities and conditions contained in the Accession Partnership with the Republic of Turkey [2003] OJ L 145, 40 .

24 Official Gazette no 25178 bis, 24 July 2003.
} 
ess started. In addition, the Council of Ministers accepted the revised Accession Partnership Documents for Turkey in January 2006 and February 2008. ${ }^{25}$ Turkey reacted to these documents with its revised National Programme for the adoption of the acquis communautaire dated 31 December 2008. ${ }^{26}$

At present, negotiations are still ongoing. Some chapters have been opened for negotiations and some are on the waiting list. ${ }^{27}$ It is assumed that it will be a long process for Turkey to become a member of the EU. In my view, there should be no reason why Turkey should not be a member as long as it complies with the standards of the EU. ${ }^{28}$

\section{Association law}

Association law represents the rules and procedures of the association relationship. For the purposes of this study, I will first briefly introduce the substance of association law and then demonstrate the effects of association law in the legal order of the EC.

\section{A. The essence of association law}

The term 'the essence of association law' includes both the institutional and material aspect of the relationship. These will be examined in turn.

\section{a. Institutions of association law}

Only one institution was formed by the Association Agreement, though new ones have emerged with the passage of time. ${ }^{29}$ Currently,

25 Council Decision 2006/35/EC of 23 January 2006 on the principles, priorities and conditions contained in the Accession Partnership with the Republic of Turkey [2006] OJ L 22, 34. Council Decision 2008/157/EC of 18 February 2008 on the principles, priorities and conditions contained in the Accession Partnership with the Republic of Turkey and repealing Decision 2006/35/EC [2008] OJ L 51.

26 Official Gazette no 27097 bis, 31 December 2008.

27 'Science and Research' has been opened and provisionally closed, while 'Free Movement of Capital', 'Company Law', 'Intellectual Property Law', 'Information Society and Media', 'Statistics', 'Enterprise and Industrial Policy', 'Trans-European Networks', 'Consumer and Health Protection' and 'Financial Control' have been opened. See the website of the Secretariat General for EU Affairs: <http://www.abgs.gov.tr/index.php?p=65\&l=2> accessed 28 March 2009.

28 See SC Blommendal, HJ Sepers and GAM Strijards, Turkey, the Union and the Netherlands (EULEC, Brussels 2004) 28; T Arat, 'Avrupa Birliği ile Türkiye Arasındaki Illişkiler ve Gümrük Birliğinin Yeri' (1995) 44 Ankara Üniversitesi Hukuk Fakültesi Dergisi 589-590; R Karluk, 'Dört Özgürlük Modeli ve Uygulaması' in Türkiye Barolar Birliği, Avrupa Birliği Hukuku ve Avrupa Kurumları Sempozyumu (30 Mart-1 Nisan 2005) (Şen Matbaa, Ankara 2006) 133.

29 For the institutional framework of other agreements concluded by the Community, see K Lenaerts and E De Smijter, 'The European Community's Treaty-Making Competence' (1996) 16 Ybk Eur Law 47-53. 
the institutions of the association are as follows: the Association Council, Association Committee, Joint Parliamentary Commission, Customs Cooperation Committee and Customs Union Joint Committee.

The Association Council is the key institution. ${ }^{30}$ It is designed 'to ensure the implementation and the progressive development of the association' ${ }^{31}$ For this reason, it has decision-making and conflict-solving powers with regard to the substance of the association. ${ }^{32}$ The competence of the Council may be provided by association law or it may enact rules in the absence of provisions conferring competence, where the attainment of an objective of the Association Agreement calls for joint action. ${ }^{33}$ The Association Council, which acts unanimously, is composed of members from the Governments of the Member States, the Council and the Commission on the one hand, and the Turkish Government on the other. ${ }^{34}$

All other institutions are formed by the Association Council either for the performance of its tasks or to ensure the continuing co-operation necessary for the proper functioning of the association. ${ }^{35}$ The Association Committee, which was formed in 1964, consists of experts and assists the Association Council in its work. ${ }^{36}$ The Joint Parliamentary Commission, which was established in 1965, involves members of the Turkish and European Parliaments and is responsible for the evaluation of the problems caused by association law. ${ }^{37}$ The Customs Co-operation Committee, which dates back to 1969, comprises customs experts and provides the necessary co-operation with regard to customs issues. ${ }^{38}$ The Customs Union Joint Committee, which was set up in 1995, consists of representatives of the parties and carries out exchanges of views and information. ${ }^{39}$

\section{b. The content of association law}

The content of the association was inspired by the Founding Treaties of the Community. ${ }^{40}$ Hence, it covers the areas relating to the four

30 For detailed information, see Can and Özen (n 6) 87-102; Günuğur (n 6) 114-128.

31 Art 6 Ankara Agreement.

32 Arts 22-25 Ankara Agreement.

33 Arts 22(1) and 22(3) Ankara Agreement. Compare with arts 5 and 308 TEC.

34 Art 23 Ankara Agreement.

35 Art 24(3) Ankara Agreement.

36 ACD 3/64.

37 ACD 1/65.

38 ACD 2/69.

39 Arts 52-53 ACD 1/95 [1996] OJ L 35 (n 16) 1.

40 Lenski argues that the substantive provisions of the Ankara Agreement are more or less shaped according to the model of the (original) EEC Treaty. Lenski (n 6) 83; E Lenski, 'Turkey (Including Northern Cyprus)' in S Blockmans and A Lazowski (eds), The European 
freedoms, transport, competition, taxation, the approximation of laws, economic policy, co-ordination of commercial policies and financial assistance. For the purposes of this study, it is useful to begin with some general remarks and then concentrate on the two general provisions on solidarity and equality.

\section{ba. General remarks}

The aim of the association is 'to promote the continuous and balanced strengthening of trade and economic relations between the parties', bearing in mind 'the need to ensure an accelerated development of the Turkish economy and to improve the level of employment and the living conditions of the Turkish people' ${ }^{41}$ Following this aim, the association explicitly foresees the possibility of membership of Turkey when it can handle the obligations arising out of the Founding Treaties, and does not mention any further conditions. ${ }^{42}$

The Ankara Agreement is a framework agreement which sets out basic rules and leaves matters to gain substance by means of further measures such as additional protocols or decisions of the Association Council. ${ }^{43}$ Association law foresees first and foremost the establishment of a customs union. ${ }^{44}$ In addition to this, the Parties agree to be guided by the principles of freedom of movement for workers, of establishment and to provide services, and also the provisions of the Founding Treaties aimed at abolishing restrictions on these freedoms between the parties. ${ }^{45}$ The provisions on transport, competition, taxation and the approximation of the laws of the Founding Treaties also need to be extended to the association. ${ }^{46}$ Economic policy, capital movements and co-ordination of commercial policies are other areas which the Parties are required to

Union and its Neighbours: A Legal Appraisal of the EU's Policies of Stabilisation, Partnership and Integration (Cambridge University Press, Cambridge 2006) 283-313, 291.

41 Art 2 Ankara Agreement.

42 Preamble and art 28 Ankara Agreement. There are some authors who state the aim is to lead to accession. Guild (n 1) 95; Blommendal, Sepers and Strijards (n 28) 28; R Holdgaard, External Relations Law of the European Community: Legal Reasoning and Legal Discourses (Kluwer Law International, the Netherlands 2008) 290; RCA White, Workers, Establishment, and Services in the European Union (Oxford University Press, Great Britain 2004) 208. In addition, there are some authors who believe that the Ankara Agreement does not offer any explicit prospect of future EU membership. Lenaerts and De Smijter (n 29) 20.

43 See Can and Özen (n 6) 75; Arat (n 28) 594.

44 Arts 2(2) and 10 Ankara Agreement.

45 Arts 12-14 Ankara Agreement.

46 Arts 15-16 Ankara Agreement. 
strengthen in the future. ${ }^{47}$ Lastly, financial assistance is also part of the association. ${ }^{48}$

bb. Solidarity and equality

Here, I want to mention two provisions which in my view have the capability of effecting further developments in association law: the solidarity and equality provisions of the Ankara Agreement.

According to Article 7 of the Ankara Agreement:

The Contracting Parties shall take all appropriate measures, whether general or particular, to ensure the fulfilment of the obligations arising from this Agreement.

They shall refrain from any measures liable to jeopardize the attainment of the objectives of this Agreement. ${ }^{49}$

This provision resembles the solidarity clause in Article 10 TEC. However, it is debatable whether it may be used as its equivalent in the sphere of association law. ${ }^{50}$ According to the European Court of Justice (ECJ), this Article refers to the obligation to implement international agreements in good faith. ${ }^{51}$ However, there is one more interpretation of this Article by the ECJ which may gain more importance in the future. It sees Article 7 of the Ankara Agreement in conjunction with Article 211 TEC, which defines the Commission 'as guardian of the EC Treaty and of the agreements concluded under it'. ${ }^{52}$ Taken together, these Articles require that 'the Commission take all appropriate measures, whether general or particular, to ensure the fulfilment of the obligations arising from [the Ankara] agreement'. ${ }^{53}$ In this regard, an interesting case is the one pending against the Kingdom of the Netherlands brought before the

\footnotetext{
47 Arts 17-21 Ankara Agreement.

48 See Can and Özen (n 6) 287-288; Günuğur (n 6) 251-258; Arat (n 28) 598-599.

49 This Article does not have direct effect. Case 12/86 Meryem Demirel $v$ Stadt Schwäbisch Gmünd [1987] ECR-3719 paras 23-24.

50 See Guild (n 1) 91.

51 Case C-192/89 Sevince v Staatssecretaris van Justitie [1990] ECR I-3461 para 23. The Court of First Instance (CFI) also mentioned that 'the provision expresses the pacta sunt servanda principle and the principle of good faith which must govern the conduct of the parties to an agreement in public international law'. Joined Cases T- 86/97, T-187/97, T190/97 to T-192/97, T-210/97, T-211/97, T-216/97 to T-218/97, T-279/97, T-280/97, T-293/97 and T-147/99, Kaufring AG and Others $v$ Commission of the European Communities [2001] ECR II-1337 para 237.

52 Case C-204/07 P C.A.S. SpA v Commission of the European Communities 25 July 2008, nyr, para 95.

53 P C.A.S. SpA (n 52) para 96.
} 
ECJ by the Commission. ${ }^{54}$ The Commission asserts for the first time that the rules of a Member State are contrary to association law and hence to Community law. ${ }^{55}$

According to Article 9 of the Ankara Agreement:

The Contracting Parties recognize that within the scope of this Agreement and without prejudice to any special provisions which may be laid down pursuant to Article 8, any discrimination on grounds of nationality shall be prohibited in accordance with the principle laid down in Article 7 of the Treaty establishing the Community. ${ }^{56}$

This provision refers to Article 12 TEC, which is especially significant with regard to the free movement of persons in Community law. Hence, we should examine the role of Article 12 TEC in Community law and then compare the situation with regard to Article 9 of the Ankara Agreement.

Article 12 TEC applies where there is no specific prohibition on discrimination. ${ }^{57}$ However, in Community law, there are non-discrimination rules on the freedom of movement of workers (Article 39(2) TEC), of establishment (Article 43 TEC) and to provide services (Article 49 TEC). As a result, where a situation falls within the scope of free movement of workers or freedom of establishment or to provide services, the ECJ directly relies on these specific equality clauses. ${ }^{58}$

Article 12 TEC 'requires perfect equality of treatment in Member States of persons in a situation governed by Community law and nationals of the Member State in question. ${ }^{59}$ In this regard, this Article "forbids not only overt forms of discrimination based on nationality, but also all covert forms of discrimination which, by the application of other criteria

54 Case C-92/07 Commission of the European Communities $v$ Kingdom of the Netherlands, pending.

55 The Commission based its plea on the equality principle (art 9 Ankara Agreement and art 10(1) ACD 1/80) and the standstill provisions (art 13 ACD 1/80 and art 41(1) AP).

56 Though not mentioned in the judgements of the ECJ, AG Antonio la Pergola assessed this Article. Opinion of the AG in Case C-262/96 Sema Sürül v Bundesanstalt für Arbeit [1999] ECR I-2685; Opinion of the AG in Case C-37/98 The Queen and Secretary of State for the Home Department ex parte: Abdulnasir Savas [2000] ECR I-2927 paras 16-20. Ott finds this wording less precise than the comparable non-discrimination provisions of other Association Agreements, such as Article 44(3) of the Europe Agreement with Poland or Article 40 of the former Moroccan Cooperation Agreement. A Ott, 'The Savas Case - Analogies between Turkish Self-Employed and Workers?' (2000) 2 European Journal of Migration and Law 455.

57 Case C-18/93 Corsica Ferries Italia v Corpo dei Piloti del Porto di Genova [1994] ECR I1783 para 19.

58 See Case C-193/94 Criminal proceedings against Sofia Skanavi and Konstantin Chryssanthakopoulos [1996] ECR I- 929 paras 20-22.

59 Case C-43/95 Data Delecta Aktiebolag and Ronny Forsberg v MSL Dynamics Ltd [1996] ECR I-4661 para 16. 
of differentiation, lead in fact to the same result.' ${ }^{60}$ However, where there is indirect discrimination, national measures can be justified by objective circumstances. ${ }^{61}$ In order to be considered as justified, the national measure should be 'based on objective considerations independent of the nationality of the persons concerned and proportionate to the legitimate aim of the national provisions. ${ }^{\prime 62}$

Article 9 of the Ankara Agreement will also apply where there is no specific prohibition on discrimination regulated by association law. There are only two specific non-discrimination clauses, both of which concern workers: Article $37 \mathrm{AP}$ and Article $10 \mathrm{ACD} 1 / 80 .{ }^{63}$ Hence, there is no specific rule of equality on freedom of establishment and to provide services. Article 9 of the Ankara Agreement may therefore intervene in this regard.

In my view, when we consider Article 41(1) AP in conjunction with Article 9 of the Ankara Agreement in a situation which is governed by Community law, Turkish nationals and the citizens of the Member State(s) in question deserve equal treatment. ${ }^{64}$ As an example, the Commission sued

60 Case 22/80 Boussac Saint-Frères SA v Brigitte Gerstenmeier [1980] ECR 3427 para 9; Case C-398/92 Mund \& Fester v Hatrex Internationaal Transport [1994] ECR I-467 para 14; Case C-388/01 Commission of the European Communities $v$ Italian Republic [2003] ECR I-721 para 13; Opinion of the AG in Case C-103/08 Arthur Gottwald v Bezirkshauptmannschaft Bregenz, delivered on 30 April 2009, para 55.

61 Mund \& Fester (n 60) para 17.

62 Case C-274/96 Criminal proceedings against Horst Otto Bickel and Ulrich Franz [1998] ECR I-7637 para 27; Case C-209/03 The Queen (on the application of Dany Bidar) $v$ London Borough of Ealing, Secretary of State for Education and Skills [2005] ECR I-2 119 [2005] para 54; Opinion of the AG in Arthur Gottwald (n 60) para 58.

63 Article 10 ACD 1/80 has direct effect: Case C-171/01 Wählergruppe 'Gemeinsam Zajedno/Birlikte Alternative und Grüne GewerkschafterInnen/UG' [2003] ECR I-4301 para 67. See also Case C-152/08 Real Sociedad de Fútbol SAD, Nihat Kahveci v Consejo Superior de Deportes, Real Federación Española de Fútbol, 25 June 2008, nyr.

Can and Özen argue that the prohibition of non-discrimination has direct effect not only against the state, but also against the employee in the employment relationship. Can and Özen (n 6) 252. See also H Can, Türkiye-Avrupa Topluluğu Ortaklık Hukukunda Kişilerin Serbest Dolaşımı: Türk Vatandaşlarının Serbest Dolaşımına İlişkin Avrupa Toplulukları Adalet Divanı Kararlarının Çevirileri (Türkiye Odalar ve Borsalar Birliği, Ankara 2006) 60. In contrast, as regards the horizontal direct effect of provisions of international agreements, Peers claims that the Court is likely to be reluctant to grant third-country nationals a remedy which was initially designed to enforce Member States' obligations to one another and to ensure the uniformity of EU law. S Peers, 'Towards Equality: Actual and Potential Rights of Third-country Nationals in the European Union' (1996) 33 CML Rev, 30. In a different context, Cremona considers the equality provisions in Europe Agreements to be directly effective. However, she thinks that their enforceability against a private employer is perhaps more debatable. M Cremona, 'Movement of Persons, Establishment and Services' in M Maresceau (ed) Enlarging the European Union: Relations between the EU and Central and Eastern Europe (Longman, USA 1997) 198.

64 Hedemann-Robinson acknowledges the self-employed as a matter clearly falling within the scope of the Ankara Agreement. M Hedemann-Robinson, 'An Overview of Recent Legal Developments at Community Level in relation to Third Country Nationals within the EU' (2001) 38 CML Rev 546. 
the Kingdom of Netherlands because of its system of administrative fees for the issue of residence permits. Those imposed on nationals of Member States ${ }^{65}$ for the issue of an equivalent document were lower than those applied to Turkish nationals who had a right of residence in the Netherlands on the basis of the Ankara Agreement, Additional Protocol or ACD $1 / 80$. According to the Commission, the Netherlands had failed to fulfil its obligations under Article 9 of the Ankara Agreement, Article 41(1) AP and Article 10(1) and 13 ACD 1/80. In short, the Commission relied on the equality clause in conjunction with the standstill clauses relating to workers and freedom of establishment and to provide services. ${ }^{66}$

Article 9 of the Ankara Agreement may also prohibit indirect discrimination, since this provision explicitly refers to Article 12 TEC, which forbids covert discrimination. Nevertheless, where there is an indirectly discriminatory measure, it might be justified when it is based on objective considerations independent of the nationality of the persons concerned and proportionate to the legitimate aim of that measure.

We are still in need of clarification of the role of Article 9 of the Ankara Agreement with regard to Community law. ${ }^{67}$ In my view, this provision has the capacity to have effects similar to its counterpart in Community law. ${ }^{68}$ The Court may apply this Article to a situation either in combination with, inter alia, Article 41(1) AP or alone. In this regard, the decision of the Court in the pending case Commission $v$ Netherlands may shed some light on this point. ${ }^{69}$

\section{B. Effects of association law on the Community legal order}

It is time to move on to the next section: the effects of association law on the legal order of the Community. ${ }^{70}$ In order to understand how asso-

\footnotetext{
65 This is also the case for the nationals of Norway, Iceland, Liechtenstein and Switzerland.

66 Case C-92/07 Commission of the European Communities $v$ Kingdom of the Netherlands (pending).

67 Peers states that Article 9 of the Ankara Agreement is a potential 'wild card'. When it is invoked, the Court may either declare it nugatory because of the lack of EC Treaty parallels, or it may begin to develop a sui generis interpretation of the clause which reflects the distinct nature of EC-Turkish relations. Peers (n 63) 18-19. Hedemann-Robinson recognises that Article 9 of the Ankara Agreement might well have direct effect in conjunction with other legal instruments underpinning association arrangements, by way of analogy with Article 12 TEC. Hedemann-Robinson (n 64) 542.

68 In this regard, this equality clause may serve as a basis where direct and indirect discrimination are prohibited regarding freedom of establishment and to provide service in association law in combination with Article 41(1) AP (and also Articles 13 and 14 of the Ankara Agreement).

69 Commission $v$ Netherlands (n 66).

70 Lenski warns that European Union citizens still face substantial obstacles when doing business in Turkey. Lenski (n 40) 297. For the opposite side of the coin, ie the effects
} 
ciation law has certain effects on Community law, I will examine the issue step by step. Firstly, I will explain the jurisdiction of the ECJ with regard to international agreements and, as a sub-category, mixed agreements. Secondly, I will examine the method of interpretation of the Court with regard to association law. Lastly, I will supply the conditions for direct effect regarding the provisions of association law.

\section{a. Jurisdiction and mixed agreements}

The Community concluded the Ankara Agreement on the basis of Articles 238 and 228 TEEC. ${ }^{71}$ However, not only the Community but also the Member States are party to this Agreement. Hence, the competence is shared between the Community and the Member States. This is what we call a mixed agreement, of which the Ankara Agreement is an example. ${ }^{72}$

There were several issues on the table waiting to be solved by the judiciary at the beginning: the jurisdiction of the ECJ regarding, first, international agreements, secondly, mixed agreements and thirdly the decisions of the organs established by such agreements.

The first step was taken in the Haegeman case, where the ECJ ruled that it had jurisdiction to give preliminary rulings with regard to international agreements concluded by the Community. ${ }^{73}$ The reason was simple: these agreements were concluded by the Council; hence, they are an act of one of the institutions of the Community within the meaning of Article 177(1) (b) TEEC. ${ }^{74}$ Next, there was the far-reaching statement of the Court that 'the provisions of the agreement, from the coming into force thereof, form an integral part of Community law' ${ }^{75}$ Hence, the interpretation of these agreements fell within the jurisdiction of the Court, ${ }^{76}$ which meant that the effects of these agreements would also be determined by the Community, not by the Member States. ${ }^{77}$

of association law on the legal order of the Republic of Turkey, see Can (n 63) 24-27; K Başlar and E İshakoğlu, 'Turkey' in AE Kellermann, J Czuczai, S Blockmans, A Albi and WT Douma, The Impact of EU Accession on the Legal Orders of New EU Member States and (Pre-) Candidate Countries: Hopes and Fears (Cambridge University Press, Cambridge 2006) 195-238, 195-202.

71 Articles 238 and 228 TEEC are now Articles 310 and 300 TEC. For the scope of Article 238 TEEC, see Lenaerts and De Smijter (n 29) 16-19.

72 See H Staples, The Legal Status of Third Country Nationals Resident in the European Union (Kluwer Law International, the Netherlands 1999) 101; Guild (n 1) 71-73; Lenaerts and De Smijter (n 29) 9-11.

73 Case 181/73 R. \& V Haegeman $v$ Belgian State [1974] ECR 449 paras 2-4.

74 Haegeman (n 73) paras 3-4. (Article 177(1) (b) TEEC is now Article 234(1) (b) TEC).

75 Haegeman (n 73) para 5.

76 Haegeman (n 73) para 6.

77 See JHJ Bourgeois, 'Effects of International Agreements in European Community Law: Are the Dice Cast?', (1984) 82 Michigan Law Review s 1264. 
The second step was taken in the Demirel case where it was decided that, though the agreement was mixed in nature, the ECJ had the jurisdiction to interpret the rules of association law regarding the free movement of workers as they relate to the competences of the Community. ${ }^{78}$ The jurisdiction issue was raised by the Governments of Germany and the United Kingdom. According to them, in the case of mixed agreements, 'the Court's interpretative jurisdiction does not extend to provisions whereby Member States have entered into commitments with regard to Turkey in the exercise of their own powers' ${ }^{79}$ However, referring to the Haegeman case, where it was stated that such agreements form an integral part of Community law, the Court mentioned that as association agreements create special and privileged links with a non-member country, the Community must necessarily be empowered to guarantee commitments towards that country 'in all the fields covered by the Treaty'. ${ }^{80}$ Setting the rule in this way, it was easy for the ECJ to conclude that as a field covered by the Treaty, provisions of association law relating to the free movement of workers fell within the jurisdiction of the Court. ${ }^{81}$

The third step was taken in the Greece $v$ Commission case, where the ECJ adjudged that the decisions of the Association Council also form an integral part of the Community legal system from their entry into force, since they are 'directly connected with the Association Agreement'. ${ }^{82}$ Consequently, the Court has jurisdiction in interpreting them. ${ }^{83}$

To summarise, the issues under discussion have been solved by the ECJ as follows: the ECJ has jurisdiction with regard to, first, agreements concluded by the Community, secondly, the provisions of mixed agreements as long as the commitments towards the other party are in the fields covered by the Treaty, and lastly, the decisions of the Association Council.

78 Case 12/86 Meryem Demirel v Stadt Schwäbisch Gmünd [1987] ECR-3719 para 12. For a criticism of the judgement, see Guild (n 1) 73-76. For a detailed analysis related to the jurisdiction of the Court regarding mixed agreements, see J Heliskoski, 'The Jurisdiction of the European Court of Justice to Give Preliminary Rulings on the Interpretation of Mixed Agreements' (2000) 69 Nordic Journal of International Law 395-412; A Dashwood, 'Preliminary Rulings on the Interpretation of Mixed Agreements' in D O'Keeffe (ed), Judicial Review in European Union Law (Kluwer Law International, the Netherlands 2000) 167-175; R Holdgaard, 'Principles of Reception of International Law in Community Law' (2006) 25 Ybk Eur Law 288-307.

79 Demirel (n 78) para 8.

80 Demirel (n 78) paras 7, 9.

81 Demirel (n 78) paras 9, 12.

82 Case 30/88 Hellenic Republic $v$ Commission of the European Communities [1988] ECR 3711 para 13.

83 Sevince (n 51) paras 9, 15. The German Government insisted that the Court had no jurisdiction with regard to decisions of the Association Council. However, the Court rejected their argument. Case C-237/91 Kazim Kus v Landeshauptstadt Wiesbaden [1992] ECR I-6781 para 9. 


\section{b. Interpretation}

As it comes under the jurisdiction of the ECJ, the next important question is how the provisions of association law will be interpreted. The ECJ deems an association agreement as creating special and privileged links with a non-member country. ${ }^{84}$ Therefore, it is fair to expect that the Court will use the principle of effectiveness when it interprets the provisions of association law. ${ }^{85}$

We may obtain a clue regarding the method of interpretation of association law in the Bozkurt case. The Court, dealing with the provisions of ACD 1/80 relating to workers, firstly took into account the aim of the Decision, which was securing the free movement of workers guided by the provisions of the Founding Treaties. ${ }^{86}$ Secondly, the Court stated that: 'In order to ensure compliance with that objective, it would seem to be essential to transpose, so far as is possible, the principles enshrined in those articles to Turkish workers who enjoy the rights conferred by Decision No $1 / 800^{87}$

This gives us the insight that whenever the Court deals with the provisions of association law, bearing in mind the objective of the related provisions, it interprets these provisions, as far as possible, in compli-

84 Demirel (n 78) para 9. Feld defines the objectives of association agreements as the creation of a relationship exceeding that which can be attained by the conclusion of a trade or commercial accord but falling short of the acquisition of full membership. W Feld, "The Association Agreements of the European Communities: A Comparative Analysis' (1965) 19 International Organization 227.

85 For a similar view see, K Hailbronner, Immigration and Asylum Law and Policy of the European Union (Kluwer Law International, the Netherlands 2000) 220.

86 Case C-434/93 Ahmet Bozkurt v Staatssecretaris van Justitie [1995] ECR I-1475 para 19. Hedemann-Robinson says that this guidance has had a significant influence on the ECJ's approach to interpreting the scope of association accords and instruments, especially where the arrangements are silent on definitions and explanations of various key phrases in the texts. Hedemann-Robinson (n 64) 542.

87 Bozkurt (n 86) para 20. According to Peers, this finding falls just short of declaring that 'worker' must be interpreted identically, but suggests very strongly that the Court will indeed reach this conclusion. Peers (n 63) 21. According to Guild, once the issue of the purpose and intent of an agreement has been resolved, in the absence of very strong countervailing factors, a consistent interpretation of the concept of a worker and his or her family members contained in the EC Treaty and third-country agreements is appropriate. Guild (n 1) 163. In contrast, Hailbronner finds the Court's methodology in this judgement far from convincing. Hailbronner (n 85) 229-231. Hedemann-Robinson mentions that the Court pursues a theological approach in the interpretation of the provisions of association law in some cases and draws tight boundaries around the scope of some of the provisions thereof in others. He offers the explanation that the Court has tried to reconcile two major competing interests, namely the expectations of Turkish nationals and those of Member States regarding association law. According to him, this tension has featured as an element underlying the Court's legal reasoning and will continue to do so in the future, since no guidance by the Association Council has been given. Hedemann-Robinson (n 64) 549. 
ance with their meaning according to Community law and makes an effort to reach the same meaning..$^{88}$ In my view, this is a realistic approach, since association law, which is heavily inspired by Community law, is a tool for Turkey to access EU membership. ${ }^{89}$

\section{c. Direct effect}

Direct effect is the ability of a norm to be considered as justiciable and invoked by individuals before national authorities and courts..$^{90}$ The Court, on the one hand, has expanded its direct effect case-law to internal acts of the Community, and on the other ruled that the provisions of international agreements may also have direct effect. ${ }^{91}$

With regard to the direct effect of the provisions of international agreements, ${ }^{92}$ the ECJ explained the test in the Demirel judgement as follows:

A provision in an agreement concluded by the Community with nonmember countries must be regarded as being directly applicable when, regard being had to its wording and the purpose and nature of the agreement itself, the provision contains a clear and precise obligation which is not subject, in its implementation or effects, to the adoption of any subsequent measure. ${ }^{93}$

88 See Wählergruppe (n 63) paras 72-73; Abatay and Sahin (n 2) para 112; Case C-340/97 Ömer Nazli, Caglar Nazli and Melike Nazli v Stadt Nürnberg [2000] ECR I-957 para 55; Case C-188/00 Bülent Kurz, né Yüce v Land Baden-Württemberg [2002] ECR I-10691 para 30. See also Peers (n 63) 21. For a more general approach, see FG Jacobs, 'Direct Effect and Interpretation of International Agreements in the Recent Case Law of the European Court of Justice' in A Dashwood and M Maresceau (eds), Law and Practice of EU External Relations: Salient Features of a Changing Landscape (Cambridge University Press, Cambridge 2008) 23.

89 Rogers and Scannel mention that an examination of the objectives of an association agreement is very important as an aid to interpretation of the agreement. According to them, association law has a very clear objective, essentially that of the eventual accession of Turkey to the European Community. Rogers and Scannel (n 6) 327-328.

90 See for example: 'The direct effect which must therefore be accorded to that provision implies that the individuals to which it applies have the right to rely on it before the courts of Member States'. Savas (n 56) para 54. See Can and Özen (n 6) 260; S Baykal, Türkiye - AT Ortaklk Hukuku ve ATAD Kararları Çerçevesinde Katma Protokol'ün 41/1. Maddesinde Düzenlenen Standstill Hükmünün Kapsamı ve Yorumu (İktisadi Kalkınma Vakfı Yayınları, İstanbul 2008) 7.

91 According to Hedemann-Robinson, the closer an agreement appears to resemble the market integrative elements of the EU, such as the establishment of a free trade area or a customs union between the third country and the Union, the more likely it is that the ECJ will be amenable to arguments that its provisions should have direct effect. HedemannRobinson (n 64) 535.

92 The first case where a provision of an international agreement had direct effect is Case 87/75 Conceria Daniele Bresciani v Amministrazione Italiana delle Finanze [1976] ECR 129 paras 24-26. See also Case 17/81 Pabst \& Richarz KG v Hauptzollamt Oldenburg [1982] ECR 1331 para 28.

93 Demirel (n 78) para 14. Hedemann-Robinson argues that there is a strong case that the Court should abandon the 'purpose and nature' rule in relation to provisions on third-coun- 
The Court did not accept that Article 12 of the Ankara Agreement, Article $36 \mathrm{AP}$ and Article 7 of the Ankara Agreement were directly effective, since the former two provisions were not clear or precise enough to be directly effective and the latter was only a general obligation to co-operate, and hence it could not directly confer individual rights. ${ }^{94}$

In addition to what is said in the Demirel judgement, in the Sevince judgement the Court clearly stated that to have direct effect, the provisions of a decision of the Association Council 'must satisfy the same conditions as those applicable to the provisions of the Agreement itself. ${ }^{95}$ In this case, Articles 2(1) (b) and 7 of ACD 2/76 and Articles 6(1) and 13 ACD 1/80 were found to be directly effective. ${ }^{96}$

We can now see that a provision of association law, if it is capable of being directly effective, will have effects, derived from Community law, in the legal orders of the Community and Member States.

\section{Standstill provisions relating to workers in association law}

This section examines the standstill provision relating to workers in association law. I will first mention the relevant provisions in this regard and then turn to the impact of the standstill provision in Community law.

\section{Relevant provisions}

The relevant provisions originate from the Ankara Agreement, Additional Protocol and decisions of the Association Council.

Article 12 of the Ankara Agreement states that:

The Contracting Parties agree to be guided by Articles 48, 49 and 50 of the Treaty establishing the Community for the purpose of progressively securing freedom of movement for workers between them. ${ }^{97}$

Article 36 of the Additional Protocol asserts that:

Freedom of movement for workers ... shall be secured by progressive stages in accordance with the principles set out in Article 12 of

\footnotetext{
ty national (TCN) residents in Community agreements and use instead its standard test for direct effect as applicable to norms of the first pillar. Hedemann-Robinson (n 64) 536-537.

94 Demirel (n 78) paras 23-24.

95 Sevince (n 51) para 14.

96 Sevince (n 51) para 26.

97 (Articles 48, 49 and 50 TEEC are now Article 39, 40 and 41 TEC.) Article 12 of the Association Agreement essentially serves to set out a programme but its provisions are not sufficiently precise and unconditional to constitute rules of Community law directly applicable to the internal legal order of the Member States. Demirel (n 78) paras 23, 25.
} 
the Agreement of Association between the end of the twelfth and the twenty-second year after the entry into force of that Agreement.

According to the second Paragraph of this Article, the Association Council will decide on the rules necessary to that end.

The Association Council took a specific decision on workers in 1976 (ACD 2/76) and a general decision which included a part on workers and their family members in 1980 (ACD 1/80). These were the first two steps taken to secure the free movement of workers between the parties. ${ }^{98}$ However, a third step to accomplish this goal has never come into existence. Therefore, at present, it is ACD 1/80 which governs the situation of the parties' workers and their family members in the most detailed manner.

Both ACD 2/76 and ACD 1/80 contain standstill clauses, albeit different in scope. First, while the provision laid down in the former relates to workers, the provision set out in the latter concerns workers and their family members. Second, while ACD 2/76 was valid from 20 December 1976 to 1 December 1980, there is no such limitation on validity for ACD $1 / 80$, which has been in force since 1 December $1980 .{ }^{99}$ Nevertheless, the wording of these Articles is almost the same.

Article 7 ACD 2/76 prevents Member States from introducing new restrictions on the "conditions of access to employment applicable to workers legally resident and employed in their respective territories'.

Article 13 ACD 1/80 states that:

The Member States of the Community and Turkey may not introduce new restrictions on the conditions of access to employment applicable to workers and members of their families legally resident and employed in their respective territories.

To put this provision in context, I want to examine the other provisions in ACD 1/80: Articles 6 and 7 ACD 1/80. ${ }^{100}$ Article 6, which is directly concerned with workers, entitles them to certain rights in a Member State in accordance with the length of their legal employment, subject to their being duly registered as belonging to the labour force of that Member State. Article 7, which is related to members of workers' families, enables them to a different degree to gain employment in the host

\footnotetext{
98 Art 1 ACD 2/76; preamble ACD 1/80.

99 Art 13 ACD 2/76; art 16(1) ACD 1/80.

100 These Articles have direct effect. See, for example, for Article 6 ACD 1/80: Sevince (n 51) para 26; Case C-1/97 Mehmet Birden v Stadtgemeinde Bremen [1998] ECR I-7747 para 19; Kurz (n 88) para 26. For Article 7 ACD 1/80, see Case C-355/93 Hayriye Eroglu $v$ Land Baden-Württemberg [1994] ECR I-5113 para 17; Case C-329/97 Sezgin Ergat v Stadt Ulm [2000] ECR I-1487 para 34. For detailed information about these Articles, see Can and Özen (n 6) 222-251.
} 
Member State, conditional upon being legally resident for a certain time. Workers' children, who have completed a course of vocational training, also gain the right to employment in the state where their parents have been legally employed for three years.

There are quite a few cases regarding Article 13 ACD 1/80. Besides its narrow scope, this is most probably because of the fact that Articles 6 and $7 \mathrm{ACD} 1 / 80$, which have direct effect and contain substantive rights, render the standstill clause less attractive.

\section{Impact upon Community law}

The impact of the standstill provision upon Community law will be analysed as follows. Firstly, the direct effect of the standstill clause will be established. Secondly, the scope of the provision will be clarified, and lastly, its effects on the Community legal order and national legal orders will be shown.

\section{A. Direct effect}

According to the established case-law of the ECJ, a provision of a decision of the Association Council is directly effective "when, regard being had to its wording and the purpose and nature of the agreement itself, the provision contains a clear and precise obligation which is not subject, in its implementation or effects, to the adoption of any subsequent measure.' 101

The direct effect of Article 7 ACD 2/76 and Article 13 ACD 1/80 was the issue in the Sevince case. ${ }^{102}$ The Court cited the Demirel judgement, where it settled its direct effect test, and then evaluated the Articles in the light of these criteria. ${ }^{103}$

The Court first examined the terms of the provisions. ${ }^{104}$ According to the Court, these provisions 'contain an unequivocal "standstill" clause regarding the introduction of new restrictions on access to the employment of workers legally resident and employed in the territory of the contracting States'. ${ }^{105}$ In addition, the purpose and nature of ACD 2/76 and $1 / 80$ and also the Association Agreement indicate their being directly effective. ${ }^{106}$

101 Demirel (n 78) para 14 and Sevince (n 51) para 14.

102 Sevince (n 51) paras 5 and 13.

103 Demirel (n 78) para 14; Sevince (n 51) para 15.

104 Sevince (n 51) para 16.

105 Sevince (n 51) para 18.

106 Sevince (n 51) para 19. 
The Court demonstrated why the purpose and nature proved direct effect. It turned first to the general purpose of the Ankara Agreement, which is 'to promote the continuous and balanced strengthening of trade and economic relations between the parties'. Secondly, it mentioned the provision relating to workers (Article 12 of the Ankara Agreement). This provides that the parties will be guided by the provisions of the TEEC governing free movement of workers 'for the purpose of progressively securing freedom of movement for workers between them' and also Article 36 AP which lays down the time-limits for the attainment of this objective and authorises the Association Council to this end. ${ }^{107}$ ACD 2/76 and $1 / 80$ were adopted in order to implement these articles.

The Court clarified three more points. In the first place, the fact that Article 12 of the Ankara Agreement and Article 36 AP essentially set out a programme does not prevent the provisions of ACD from having direct effect. ${ }^{108}$ In addition to this, the direct effect of the provisions of ACD cannot be contested merely because they were not published. This may only prevent the invoking of these provisions against private individuals but not public authorities. ${ }^{109}$ Furthermore, regarding the safeguard clauses which enable the parties to derogate from provisions granting certain rights to workers, the existence of such clauses is not in itself liable to affect the direct effect of the provisions from which they allow derogations. ${ }^{110}$

In conclusion, the Court stated that Article $7 \mathrm{ACD} 2 / 76$ and Article 13 ACD 1/80 have direct effect in the Member States of the Community. ${ }^{111}$

\section{B. Scope}

The scope of the standstill clause covers three aspects: personal, material and temporal. I will deal with these in turn.

\section{a. Personal scope}

The personal scope concerns those persons who can benefit from the standstill clauses set out in Article 7 ACD 2/76 and Article 13 ACD 1/80. Both of these provisions apply to Turkish workers and the latter includes

\footnotetext{
107 Sevince (n 51) para 20.

108 Sevince (n 51) para 21.

109 Sevince (n 51) para 24.

110 Sevince (n 51) para 25.

111 Sevince ( $\mathrm{n}$ 51) para 26. This case is quoted in subsequent cases when restating the direct effect of Article 13 ACD 1/80: Abatay and Sahin (n 2) para 58; Case C-242/06 Minister voor Vreemdelingenzaken en Integratie v T Sahin 17 September 2009 nyr para 62.
} 
the family members of such workers. In the first place, those holding Turkish nationality can invoke these provisions. ${ }^{112}$ As family members' rights depend on the Turkish national, their nationality is irrelevant in this respect. ${ }^{113}$

The next logical question is who is deemed a Turkish worker and who are regarded as their family members. The terms 'worker' and 'family member' with regard to Turkish nationals have been construed in the same way as for European citizens. Therefore, a person who pursues an effective and genuine activity, and performs services for and under the direction of another person for a certain period of time and in return for remuneration is considered to be a worker. ${ }^{114}$ Since the Court uses the definition of Community workers for Turkish workers, I will refer to the definition of family members of Community workers, which is for now regulated by Directive 2004/38/EC, with regard to the families of Turkish workers. ${ }^{115}$ Consequently, the family members of a worker are: the spouse; direct descendants under the age of 21 or who are dependants, together with those of the spouse; dependent direct relatives in the ascending line and also those of the spouse. ${ }^{116}$

There is one more qualification required by these Articles with regard to Turkish workers: they have to be legally resident and employed in a Member State. ${ }^{117}$ The Court accepts that a Turkish national is lawfully resident in the territory of the host Member State when they comply with the rules of the host Member State 'as to entry, residence and, where ap-

112 See Abatay and Sahin (n 2) para 117.

113 Of course, the nationality of the family member of the Turkish worker may be relevant in accordance with Community law. For example, such a situation may occur when a Turkish worker is married to a European citizen. Enjoying the more advantageous rights he/she may get from this standstill clause, the European citizen would not be in need of relying on this article.

114 Birden (n 100) para 25. See, with regard to Article 39 TEC, Case 66/85 Deborah LawrieBlum v Land Baden-Württemberg [1986] ECR 2121 para 16-17; Case 197/86 Steven Malcolm Brown $v$ The Secretary of State for Scotland [1988] ECR 3205 para 21; Case C-357/89 VJM Raulin $v$ Minister van Onderwijs en Wetenschappen [1992] ECR I-1027 para 10. See, with regard to Article 6(1) ACD 1/80, Case C-36/96 Faik Günaydin, Hatice Günaydin, Günes Günaydin and Seda Günaydin v Freistaat Bayern [1997] ECR I-5143 para 31; Case C98/96 Kasim Ertanir v Land Hessen [1997] ECR I-5179 para 43.

115 It is not yet clear in case-law whether the Court will also apply the definition of 'family members' set out in Directive 2004/38/EC for Turkish workers.

116 Case C-275/02 Engin Ayaz v Land Baden-Württemberg [2004] ECR I-8765 para 45. See art 2(2) Directive 2004/38/EC.

117 The Court has recently shed more light on the personal scope of Article 13 ACD 1/80. This Article is not subject to the condition that the Turkish national concerned satisfy the requirements of Article $6 \mathrm{ACD} 1 / 80$. Neither is the scope of this Article restricted to Turkish migrants who are in paid employment. Sahin (n 111) para 50. In addition, family members of Turkish workers do not need to be legally resident and employed in a Member State, since their status is linked to the status of Turkish workers. 
propriate, employment'. ${ }^{118}$ The Court adds to this being lawfully resident in the territory of the host Member State 'for a sufficient period to allow them progressively to become integrated there'. ${ }^{119}$

As an example, in the Abatay/Sahin case, the Court did not consider Turkish lorry drivers engaged in international haulage as workers, since they are present in Germany for very limited periods with the sole aim of transporting goods. They also live in Turkey, the firm employing them pays them in Turkey, and they have no intention of integrating into the employment market of Germany. ${ }^{120}$ Hence, Article 13 ACD 1/80 cannot be applied in this case. ${ }^{121}$

The personal scope of this Article seems very narrow, given that it covers only Turkish workers and their family members as long as they are legally resident and employed.

\section{b. Material scope}

The material scope has two aspects: the subject-matter and internal situation.

ba. Subject-matter

Subject-matter relates to the areas and rights which are covered by Article 7 ACD 2/76 and Article 13 ACD 1/80. Although there is no case with regard to these Articles in this respect, it is possible to give an explanation by comparison with, on the one hand, the free movement of workers in the Community and, on the other, the standstill provision in association law concerning freedom of establishment and to provide services.

In order to clarify the subject, first, I will start with what is not covered. As standstill provisions are quasi-procedural rules, as opposed to substantive rules, Article 7 ACD 2/76 and Article 13 ACD 1/80 will not give any substantive right as regards first admission, freedom of movement for workers or residence. ${ }^{122}$ In addition, given that these standstill clauses require Turkish workers to be legally resident and employed, the

\footnotetext{
118 Abatay and Sahin (n 2) paras 84, 87; Sahin (n 111) para 53. As regards Article 6(1) ACD 1/80, see Birden (n 100) para 51; Nazli (n 88) para 31; Kurz (n 88) para 39.

119 Abatay and Sahin (n 2) para 117.

120 Abatay and Sahin (n 2) para 89.

121 Abatay and Sahin (n 2) para 91.

122 Compare with these cases: Savas (n 56) paras 64, 59, 65; Abatay and Sahin (n 2) paras 62, 64; Case C-16/05 The Queen, Veli Tum and Mehmet Dari $v$ Secretary of State for the Home Department [2007] ECR I-7415 para 52.
} 
Member States remain free to impose new restrictions with regard to the first admission of Turkish workers into their territory. ${ }^{123}$

I will now turn to the question of what is covered. The Court explicitly indicated that Article 13 ACD 1/80 concerns 'access to employment'. ${ }^{124}$ I will add two more areas: one is 'residence' ${ }^{125}$ as a corollary to employment and the other is 'expulsion', since there would be no access to employment in the case of expulsion. ${ }^{126}$ In all of these areas, the standstill provisions entitle Turkish workers and their family members to the right to preclude the adoption of new restrictions. In addition to this, 'first admission' will be subject to the standstill provision with regard to the family members of Turkish workers, since they do not need to be legally resident and employed beforehand, as their status is linked to legally resident and employed Turkish workers.

\section{bb. Internal situation}

The free movement provisions can apply only when there is at least one factor 'connecting them to any situations envisaged by Community law'. ${ }^{127}$ Otherwise they will be regarded as situations wholly internal to a Member State and no provision of Community law will find a sphere of application. As a result, Turkish nationals who have moved to a Member State will satisfy this condition.

This condition has always been fulfilled with regard to the cases before the ECJ in the context of Turkish workers, since it is only the national courts of Member States that can refer a case to the ECJ when disputes relating to Turkish workers arise.

\footnotetext{
123 The Court compared Article 13 ACD 1/80 with Article 41(1) AP and identified that the latter, written in a general way, was not limited in its sphere of application as the former was. The Court used this argument to come to the conclusion that Article 41(1) AP applies to the first admission rules of Member States. Tum and Dari (n 122) paras 60, 69. See also Case C-228/06 Mehmet Soysal, Cengiz Salkim, Ibrahim Savatli v Bundesrepublik Deutschland, 19 February 2009, nyr, para 62.

124 Abatay and Sahin (n 2) para 80.

125 See Sahin (n 111) para 75. Compare with: Savas (n 56) paras 65, 71; Abatay and Sahin (n 2) paras 65 and 66; Tum and Dari (n 122) para 49.

126 Rogers and Scannel talk about 'further access to employment', 'subsequent stay' and 'expulsion'. Rogers and Scannel (n 6) 352, 376.

127 Case 175/78 The Queen v Vera Ann Saunders [1979] ECR 1129 para 11. According to Mortelmans, the prohibitions (on obstacles to free movement) and exceptions (to free movement) concern restrictions imposed on trans-border economic activities. PJG Kapteyn, AM McDonnel, KJM Mortelmans, CWA Timmermans and LA Geelhoed, The Law of the European Union and the European Communities $\left(4^{\text {th }}\right.$ edn, Kluwer Law International, the Netherlands 2008) 585.
} 


\section{c. Temporal scope}

The temporal scope pertains to when Member States have been prevented from introducing new restrictions in areas covered by the standstill clauses. Initially, there was some hesitation about the temporal scope of Article 13 ACD 1/80. ${ }^{128}$

In the Abatay/Sahin case, the German Government raised this issue before the Court. They argued that, regardless of Article 13 ACD 1/80, Member States still enjoy the right to set new restrictions on access to employment for Turkish nationals. However, these new restrictions will not be applied to Turkish nationals who are already lawfully employed and thereby have a right of residence in the host state when those restrictions are introduced. ${ }^{129}$ The Court, nevertheless, rejected this argument, as such an understanding of the Article disregards the system set up by ACD 1/80 and would deprive Article 13 thereof of its effect. ${ }^{130}$ Consequently, Member States have been prevented 'generally from treating Turkish nationals less favourably than they were treated at the time of the entry into force of the "standstill" clause, that is to say, 1 December 1980'. ${ }^{131}$

To sum up, the standstill clauses prevent new restrictions from the date of entry into force of the ACD in the host Member State. ${ }^{132}$ Regarding Turkish workers, this entry into force is 20 December 1976 and as far as their family members are concerned it is 1 December 1980 for the original six Member States (Germany, France, Italy, the Netherlands, Belgium, and Luxembourg) and the States of the first enlargement (the United Kingdom, Ireland, and Denmark). For the other States, one has to check the date of their accession to the Community/Union. ${ }^{133}$

\section{Effects}

Article 13 ACD 1/80 and Article 7 ACD 1/76 preclude the application of inconsistent national rules. ${ }^{134}$ National rules which make the

128 As the wording of Article 7 ACD 2/76 and Article $131 / 80$ is almost the same, except that the latter includes family members, this should also be regarded as a challenge to the former Article.

129 Abatay and Sahin (n 2) para 75. For a similar view on the doctrine, see Can (n 63) 61-62.

130 Abatay and Sahin (n 2) para 76.

131 Abatay and Sahin (n 2) para 74.

132 Abatay and Sahin (n 2) para 117; Sahin (n 111) para 63.

133 See Rogers and Scannel (n 6) 351-352; B Çiçekli, 'The Rights of Turkish Migrants in Europe under International Law and EU Law' (1999) 33 International Migration Review 328; H Gümrükçü, $A(E) T / A B$ Türkiye Ortaklık Hukuku'nun Türkiye'ye Yansimaları ve Hizmet Sektörü (Akdeniz Üniversitesi İİBF ve TÜGİAD Vizesiz Avrupa Araştırma Grubu, Antalya 2008) 39.

134 Abatay and Sahin (n 2) para 59; Sahin (n 111) para 62. Although these judgements did not mention Article $7 \mathrm{ACD} 2 / 76$, they had the same effect as the standstill provision in ACD 
conditions related to the areas covered by these Articles more stringent than the conditions before the standstill clauses entered into force are regarded as inconsistent. ${ }^{135}$ Nevertheless, standstill clauses do not replace the substantive rule that is in conflict with them. As quasi-procedural rules, they refer to the rules of a Member State that were existent when they entered into force. ${ }^{136}$

Here, the important question is how we come to this conclusion. In other words, what is the test in determining whether a national rule conflicts with a standstill clause? Here, I will deal with two issues: the first one concerns restriction and justification issues, while the second one relates to the limits of the standstill clause.

\section{a. Restriction and justification}

Article 13 ACD 1/80 and Article 7 ACD 1/76 prevent the application of inconsistent rules of national law.

Article 13 ACD 1/80 and Article 7 ACD 2/76 preclude contradictory national measures where there is a restriction on access to employment that is considered to be a new restriction. ${ }^{137}$ When assessing whether there is a new restriction, the object or effect of the national measures will be taken into account. ${ }^{138}$

How can we define a 'restriction'? The case-law relating to the standstill regarding the self-employed may give us some hints. ${ }^{139}$ Taking the Abatay/Sahin case as a landmark, my solution is as follows: Article 12 of the Ankara Agreement and Article 36 of the Additional Protocol in concert with the objective of the association necessitate that the principles enshrined in Articles 39, 40 and 41 TEC which relate to the free movement

$1 / 80$, as their wording only differs with regard to the inclusion of 'family members' in the text of the latter standstill clause.

135 See Abatay and Sahin (n 2) para 80; Sahin (n 111) para 63.

136 Tum and Dari (n 122) para 55. See also Gümrükçü (n 133) 44.

137 Sahin (n 111) para 63; Abatay and Sahin (n 2) para 80. Compare with Abatay and Sahin (n 2) para 110.

138 Sahin (n 111) para 63. Compare with Savas (n 56) para 69; Tum and Dari (n 122) para 47.

139 Though the recently adjudicated Sahin case relates directly to Article 13 ACD 1/80, there are no explicit statements regarding how to define a 'restriction' in this judgement. Instead, the Court preferred to refer to the interpretation of Article 41(1) AP, which in the words of the Court is 'equally valid as regards the standstill obligation which is the basis of Article 13 in relation to freedom of movement for workers'. Sahin (n 111) para 65. This assertion is not surprising, since the Court had already stated that these two provisions are of the 'same kind', have the 'same meaning' and 'the objective pursued by those two clauses is identical'. See Savas (n 56) para 50; Abatay and Sahin (n 2) para 112. See also Sahin (n 111) para 65. 
of persons 'must be extended, so far as possible, to Turkish nationals who enjoy the rights conferred by Decision No 1/80'. ${ }^{140}$

The next step is to make a comparison with internal market case-law in order to assess whether national measures constitute a restriction. ${ }^{141}$ It seems to me that it is logical that the Court will bring justification into play at this stage, since the Court refers to the relevant Treaty articles and the case-law regarding their interpretation. ${ }^{142}$ At this point, I assume that the Court will be ready to hear justifications based on public interest, besides public policy, public security and public health and to apply its proportionality test, given that it refers to the restriction approach in relation to free movement rights. ${ }^{143}$

If the Court comes to the conclusion that there is a restriction, in the last stage the floor will be given to the national court to determine whether this restriction is a new one which worsens the position of Turkish nationals when compared to the rules in existence on the date of entry into force of the Additional Protocol for that State. ${ }^{144}$

\section{b. Limits}

There are certain limits to the effects of the standstill clause: abuse of rights, prohibition of favourable treatment, measures against disturbances and the equality principle. ${ }^{145}$

\footnotetext{
140 Nazli (n 88) para 55; Kurz (n 88) para 30. Compare with Abatay and Sahin (n 2) para 112.

141 An example of such a restriction can be found in Sahin (n 111) para 75. Compare with Abatay and Sahin (n 2) paras 110-111, 113-115; Tum and Dari (n 122) para 47; Soysal (n 123) paras 55-57.

142 Compare with Abatay and Sahin (n 2) para 111.

143 In the recently adjudicated Sahin case, the Court seemed receptive to considering 'justifications' as a part of the 'new restrictions' test when it stated that the Netherlands had not advanced 'any relevant argument capable of justifying' its new rules on the levels of the administrative charges related to residence permits imposed on Turkish nationals. However, the Court did not explicitly refer to justification on the grounds of public policy or public interest. Because of this, it appears that the Court has taken into account the arguments of Member States used to justify the proportionality of new rules regarding Turkish nationals. Sahin (n 111) paras 71, 73, 74 (emphasis added). Compare with the case-law relating to the standstill concerning the self-employed where the Court cited cases where the 'restriction' approach and justification on the grounds of public interest were at issue. See, for example, Abatay and Sahin (n 2) para 111, where the Court cited, inter alia, Case C-76/90 Manfred Säger v Dennemeyer \& Co Ltd [1991] ECR I-4221 para 14 when it answered the question whether there was a restriction in the main case.

144 Compare with Abatay and Sahin (n 2) para 116.

145 With regard to the abuse of rights and prohibition of favourable treatment in the context of the standstill clause concerning the self-employed, see Tum and Dari (n 122) paras 64-68; Soysal (n 123) para 61.
} 
As regards the abuse of rights, Community law recognises that Member States are entitled to take measures 'to prevent individuals from improperly or fraudulently taking advantage of provisions of Community law'. ${ }^{146}$ Turkish nationals are also not allowed to use association law improperly or fraudulently. ${ }^{147}$

As regards the prohibition of favourable treatment, this reflects Article 59 of the Additional Protocol. According to this Article, in the fields covered by this Protocol Turkey shall not receive more favourable treatment than that which Member States grant to one another pursuant to the Treaty establishing the Community'. As the workers' provisions of ACD 1/80 (and ACD 2/76) are also covered by the Additional Protocol, the standstill clauses thereof cannot give a Turkish national more favourable treatment than that which a European citizen enjoys. ${ }^{148}$ This was confirmed in the Sahin case where the Court ruled that 'the adoption of new rules which apply in the same way both to Turkish nationals and to Community nationals is not inconsistent with any of the standstill clauses laid down in the fields covered by the EEC-Turkey Association'. ${ }^{149}$

As regards measures against disturbances, this echoes Article 60 of the Additional Protocol. According to this Article, the Community or, with its authorisation, the Member State(s) may take protective measures in three situations: if there are serious disturbances in a sector of the economy of the Community or one or more Member States; if these serious disturbances prejudice the external financial stability of one or more Member States; if difficulties arise which adversely affect the economic situation in a region of the Community. ${ }^{150}$ As the rules relating to workers

146 Case C-212/97 Centros Ltd $v$ Erhvervs- og Selskabsstyrelsen [1999] ECR I-1459 para 24. See also Article 35 of Directive 2004/38/EC. See, in particular, regarding freedom to supply services, Case 33/74 Johannes Henricus Maria van Binsbergen $v$ Bestuur van de Bedrijfsvereniging voor de Metaalnijverheid [1974] ECR 1299 para 13; Case C-148/91 Vereniging Veronica Omroep Organisatie v Commissariaat voor de Media [1993] ECR I-487 para 12; Case C-23/93 TV10 SA v Commissariaat voor de Media [1994] ECR I-4795 para 21; regarding freedom of establishment, Case 115/78 J Knoors $v$ Staatssecretaris van Economische Zaken [1979] ECR 399 para 25; Case C-61/89 Criminal proceedings against Marc Gaston Bouchoucha [1990] ECR I-3551 para 14; regarding social security, Case C-206/94 Brennet AG $v$ Vittorio Paletta [1996] ECR I-2357 para 24; regarding freedom of movement for workers, Case 39/86 Sylvie Lair v Universität Hannover [1988] ECR 3161 para 43; and regarding company law, Case C-367/96 Alexandros Kefalas and Others $v$ Elliniko Dimosio (Greek State) and Organismos Oikonomikis Anasygkrotisis Epicheiriseon AE (OAE) [1988] ECR I-2843 para 20.

147 See Case C-285/95 Suat Kol $v$ Land Berlin [1997] ECR I-3069 para 29.

148 See Sahin (n 111) para 71; Soysal (n 123) para 61.

149 Sahin (n 111) para 67. See also Soysal (n 123) para 61.

150 The Association Council should be notified immediately of such measures and their content (art 60(2) Additional Protocol). In the choice of measures, preference shall be given to those which will least disturb the functioning of the Association and these measures shall not exceed what is strictly necessary to remedy the difficulties that have arisen (art 
in ACD 1/80 (and ACD 2/76) are also covered by the Additional Protocol, the standstill clauses thereof may not be applicable when the Community or the Member State(s) take such measures.

As regards equality, this principle may function as a safety net when the new restrictions of Member States are justified, since even new measures should at most be equal to those applied to EU citizens. There is a pending case which serves as an excellent example here. ${ }^{151}$ The Netherlands raised the rates of administrative fees for residence permits that are applicable to Turkish citizens in 1994. In the view of the Commission, this measure of the Netherlands constitutes a new restriction which is prohibited by the standstill clauses, inter alia, relating to workers in association law. Subsequently, the Commission states that even if the Netherlands makes Turkish nationals subject to the payment of administrative fees for residence permits, in accordance with the equality principle, such fees may not be higher than those imposed on EU citizens.

This pending case shows us that there is room for the equality principle together with the standstill clauses with regard to Turkish nationals. Nonetheless, we should wait for the judgement of the Court for clarification on this issue.

\section{The standstill provision relating to the right of establishment and freedom to provide services in association law}

This section reviews the standstill provision relating to the right of establishment and freedom to provide services in association law. ${ }^{152}$ I will firstly indicate the relevant provisions in this regard and secondly demonstrate the impact of the standstill provision in Community law.

\section{Relevant provisions}

The relevant provisions originate from the Ankara Agreement and Additional Protocol.

Article 13 of the Ankara Agreement states that:

The Contracting Parties agree to be guided by Articles 52 to 56 and Article 58 of the Treaty establishing the Community for the pur-

60(3) Additional Protocol). Consultations may take place in the Association Council on these measures (art 60(4) Additional Protocol).

151 Commission $v$ Netherlands (n 54).

152 For a comparison of the provisions relating to the right of establishment and freedom to provide services in the Ankara Agreement and Additional Protocol with the provisions in the Europe Agreements, see Cremona (n 63) 200-207. 
pose of abolishing restrictions on freedom of establishment between them. ${ }^{153}$

Article 14 of the Ankara Agreement expresses that:

The Contracting Parties agree to be guided by Articles 55, 56 and 58 to 65 of the Treaty establishing the Community for the purpose of abolishing restrictions on freedom to provide services between them. ${ }^{154}$

Article 41 of the Additional Protocol declares that:

1. The Contracting Parties shall refrain from introducing between themselves any new restrictions on the freedom of establishment and the freedom to provide services.

2. The Council of Association shall, in accordance with the principles set out in Articles 13 and 14 of the Agreement of Association, determine the timetable and rules for the progressive abolition by the Contracting Parties, between themselves, of restrictions on freedom of establishment and on freedom to provide services.

Although it is the duty of the Association Council to remove progressively the restrictions on freedom of establishment and to provide services, to date, no such decision has been adopted by the Council. ${ }^{155}$ Hence, the only legal weapon in the armoury of Turkish nationals with regard to establishment and services is the standstill clause in Article $41 \mathrm{AP}$.

\section{Impact upon Community law}

The impact of the standstill provision upon Community law will be analysed as follows. Firstly, the direct effect of the standstill clause will be verified, and secondly, the scope of the provision will be explained. Lastly, its effects on the Community legal order will be illustrated.

\section{A. Direct effect}

According to the established case-law of the ECJ, a provision of an international agreement is directly effective "when, regard being had to its wording and the purpose and nature of the agreement itself, the provision

\footnotetext{
153 Articles 52-56 and Article 58 TEEC are now Articles 43, 46 and 48 TEC. This Article does not have direct effect. Tum and Dari (n 122) para 62.

154 Articles 55-56 and 58-65 TEEC are now Articles 45, 46 and 48-55 TEC. This Article does not have direct effect. Savas (n 56) paras 42-45.

155 Staples defines this situation by stating that the right to establishment and to provide services in the Ankara Agreement has therefore remained a paper right as far as Turkish nationals are concerned. Staples (n 72) 256, 259.
} 
contains a clear and precise obligation which is not subject, in its implementation or effects, to the adoption of any subsequent measure. ${ }^{156}$

The direct effect of Article 41 AP was the question in the Sava case. ${ }^{157}$ The Court, after mentioning the test for the direct effect of provisions of international agreements, began analysing whether Article 41 AP satisfies the criteria. ${ }^{158}$

The Court, taking the wording as its basis, stated that Article 41 AP 'lays down, clearly, precisely and unconditionally, an unequivocal "standstill" clause, prohibiting the contracting parties from introducing new restrictions on the freedom of establishment as from the date of entry into force of the Additional Protocol'. ${ }^{159}$

Thereafter, the Court relied on three similar standstill provisions which had been found directly effective: Article 53 TEEC, Article 7 ACD 2/76 and Article 13 ACD 1/80. Firstly, the Court made an analogy with Article 53 TEEC, which prevents Member States from introducing new restrictions on the right of establishment and is "legally complete in itself and therefore capable of producing direct effects'. ${ }^{160}$ Since the wording of Article $41 \mathrm{AP}$ is almost identical to that of Article 53 TEEC, it must also be regarded as being directly effective. ${ }^{161}$ Secondly, the Court cited the Sevince judgement, where it considered the standstill clauses set out in Article 7 ACD 2/76 and Article 13 ACD 1/80 as having direct effect. ${ }^{162}$ The Court considered Article $41 \mathrm{AP}$ as a provision of the same kind; hence, it should also be directly effective. ${ }^{163}$

The Court, subsequently, turned to the question of the purpose and subject-matter of the Association Agreement. Neither of these was capable of preventing the provisions contained therein from being directly effective. The purpose of the Agreement is 'to promote the development of trade and economic relations between the contracting parties', which includes 'the progressive abolition of restrictions on freedom of establishment' and to 'facilitate the accession of the Republic of Turkey to the Community at a later date'. ${ }^{164}$

\footnotetext{
156 Demirel (n 78) para 14.

157 Savas (n 56) para 36.

158 Savas (n 56) paras 39-40. See also Demirel (n 78) para 14; Sevince (n 51) para 15; Case C-262/96 Sema Sürül v Bundesanstalt für Arbeit [1999] ECR I-2685 para 60.

159 Savas (n 56) para 46. In contrast, Hailbronner asserts that this provision is conditional because of its second paragraph where it empowers the Association Council to take necessary measures. Hailbronner (n 85) 234.

160 Savas (n 56) para 47; Case 6/64 Flaminio Costa v E.N.E.L [1964] ECR 585, 596.

161 Savas (n 56) para 48.

162 Savas (n 56) para 49; Sevince (n 51) paras 18, 26.

163 Savas (n 56) para 50.

164 Savas (n 56) para 52.
} 
The Court shed light on one more point. Although there is an imbalance as regards the obligations between the parties, this does not prevent the provisions of association law from being directly effective. ${ }^{165}$

From the above, it is clear that Article 41(1) AP has direct effect. ${ }^{166}$

\section{B. Scope}

The scope of the standstill clause comprises three aspects: personal, material and temporal. I will examine them in turn.

\section{a. Personal scope}

The personal scope concerns those persons who can benefit from the standstill clause set out in Article 41 AP. It is implicit from this Article that in order to invoke it, on the one hand, any natural person has to hold Turkish nationality, while on the other, undertakings must be established in Turkey. ${ }^{167}$ However, albeit in very limited situations, it seems that Community nationals and undertakings may also rely on this provision against their own or host Member State. ${ }^{168}$

To benefit from this provision, Turkish nationals or undertakings should try to use their rights concerning freedom of establishment or to provide services. In accordance with the case-law of the ECJ which transposes the principles of the internal market, as far as is possible, to association law, I will use the internal-market meaning of these terms in order to describe them. ${ }^{169}$

165 Savas (n 56) para 53. See also Sürül (n 56) para 72; Bresciani (n 92) para 23; Case C18/90 Office National de l'Emploi v Kziber [1991] ECR 199 para 21; Case C-469/93 Amministrazione delle Finanze dello Stato v Chiquita Italia [1995] ECR I-4533 para 34.

166 Savas (n 56) para 54. This case is quoted in subsequent cases when restating the direct effect of Article 13 ACD 1/80: Abatay and Sahin (n 2) para 58; Tum and Dari (n 122) para 46; Soysal (n 123) para 45.

167 See, in turn, Savas (n 56) para 69 and Abatay and Sahin (n 2) para 105.

168 I come to this conclusion because of the departure rights extended to Community nationals and undertakings within the scope of freedom of establishment and to provide services. See Case 81/87 The Queen v HM Treasury and Commissioners of Inland Revenue, ex parte Daily Mail and General Trust plc [1988] ECR 5483 para 16; Case C-264/96 Imperial Chemical Industries plc (ICI) $v$ Kenneth Hall Colmer (Her Majesty's Inspector of Taxes) [1998] ECR I-4695 para 21; Case C-200/98 X AB, Y AB v Riksskatteverket [1999] ECR I-8261 para 26; Case C-251/98 C Baars $v$ Inspecteur der Belastingdienst Particulieren/Ondernemingen Gorinchem [2000] ECR I-2787 para 28.

169 Abatay and Sahin (n 2) para 112. See also UM Aksoy, Avrupa Hukuku Açısından Türk Vatandaşlarına Uygulanan Vize Alma Mecburiyetinin Değerlendirilmesi Raporu (İktisadi Kalkınma Vakfı Yayınları, İstanbul 2008) 23-24; Dienelt in K Dienelt, H Kabaalioğlu and UM Aksoy, Türk Vatandaşlarının Avrupa'ya Seyahat Özgürlüğünün Kısıtlanması (İktisadi Kalkınma Vakfı Yayınları, İstanbul 2008) 9. 
The freedom of establishment, as regards individuals, requires a person to be self-employed. A person who pursues an economic activity is regarded as self-employed when he/she works outside any relationship of sub-ordination, under his/her own responsibility and in return for remuneration paid directly to him/her directly and in full. ${ }^{170}$ As regards undertakings, the undertaking should actually be established in the host Member State and pursue genuine economic activity there. ${ }^{171}$

The freedom to provide services covers groups which can be divided into three depending on where the service provider moves, where the service recipient moves or whether it is neither the provider nor the recipient which moves, but the service. ${ }^{172}$ In order to be 'services' within the meaning of the Treaty, a 'service', which is 'temporary', should be 'normally provided for remuneration'. ${ }^{173}$ In spite of the wording of Article 50 TEC, which mentions only service providers, the Court decided that service recipients also benefit from the Article, since it is a 'necessary corollary' of freedom to provide services. ${ }^{174}$ The people who are regarded as service recipients are tourists, persons receiving medical treatment and persons travelling for the purpose of (private) education or business. ${ }^{175}$ Furthermore, the service may move by telephone, internet or cable without any movement from either provider or recipient. ${ }^{176}$

The freedom to provide services also shows a special characteristic as regards undertakings. Article 41(1) AP can be invoked not only by undertakings established in Turkey, but also by the workers of that undertaking, since workers of the service provider are 'indispensable to enable him to provide his services'. ${ }^{177}$

\footnotetext{
170 See Case C-268/99 Aldona Malgorzata Jany and Others $v$ Staatssecretaris van Justitie [2001] ECR I-8615 para 71.

171 See Case C-196/04 Cadbury Schweppes plc, Cadbury Schweppes Overseas Ltd v Commissioners of Inland Revenue [2006] ECR I-7995 para 54.

172 See C Barnard, The Substantive Law of the EU: The Four Freedoms $\left(2^{\text {nd }}\right.$ edn, Oxford University Press, Great Britain 2007) 355-358; Baykal (n 90) 31; Aksoy (n 169) 23. See also Dienelt (n 169) 8, 11-12.

173 Art 50 TEC.

174 Joined Cases 286/82 and 26/83 Graziana Luisi and Giuseppe Carbone v Ministero del Tesoro [1984] 377 para 10. See also Article 1/b of (repealed) Directive 73/148/EEC ([1973] OJ L 172).

175 Luisi and Carbone (n 174) para 10 and Case C-109/92 Stephan Max Wirth $v$ Landeshauptstadt Hannover [1993] ECR I-6447 para 17.

176 See Barnard (n 172) 357-358.

177 Abatay and Sahin (n 2) paras 105-106. See also Soysal (n 123) para 46. Compare with Case C-350/96 Clean Car Autoservice GesmbH v Landeshauptmann von Wien [1998] ECR I-2521 paras 19-21.
} 
b. Material scope

The material scope consists of two aspects: the subject-matter and internal situation.

ba. Subject-matter

The subject-matter concerns the areas which are covered by Article 41(1) AP. At this stage, thanks to the case-law of the ECJ, we have a reasonable list to consult with regard to those areas covered by this standstill clause. It is still helpful, however, to look at the case-law of the Court relating to internal market freedoms, since the principles enshrined there, so far as is possible, will be transposed to association law. ${ }^{178}$

Article 41(1) AP covers both freedom of establishment and to provide services. Firstly, as regards services, I will try to answer what constitutes services. Secondly, regarding establishment and services, I will explain what rights are covered by them.

Firstly, in order to answer what constitutes services, the treaty articles and case-law of the ECJ are useful sources. Article 50 TEC includes a list of services which are activities of craftsmen, professions and activities of an industrial or commercial character. Article 51 TEC excludes transport, banking and insurance services from the provision of services. In addition to this, the case-law clarifies that tourism, medical, financial, business, educational and sporting activities also constitute services. ${ }^{179}$

This list can also be applied to association law, except for transport. In the Abatay/Sahin case, the Government of the Netherlands argued that the transport sector is not covered by Article 41(1) AP. In the view of the Government, there was a provision in association law dealing with transport separately, while this sector is also excluded from the provision of services in Community law. ${ }^{180}$ However, the Court decided to the contrary. According to the Court, the position of transport in Community law is different from its position in association law. ${ }^{181}$ The transport provisions in association law, Article 15 of the Ankara Agreement and Article 42 AP, show that the extension of the Treaty provisions on trans-

\footnotetext{
178 Abatay and Sahin (n 2) para 112.

179 See Barnard (n 172) 359-360. See Luisi and Carbone (n 174) para 10; Case 352/85 Bond van Adverteerders and Others $v$ Netherlands State [1988] ECR 2085 para 16; Joined cases C-51/96 and C-191/97 Christelle Deliège $v$ Ligue francophone de judo et disciplines associées ASBL, Ligue belge de judo ASBL, Union européenne de judo and François Pacquée [2000] ECR I-2549 para 56.

180 Abatay and Sahin (n 2) para 92.

181 Abatay and Sahin (n 2) para 95.
} 
port to Turkey is merely optional and so far had not been achieved. ${ }^{182}$ Consequently, 'unlike intra-Community transport, transport services in the context of the Association cannot be removed from the ambit of the general rules applicable to the provision of services'. ${ }^{183}$

As regards the rights covered by Article 41(1) AP, I will begin with what is not covered. As a quasi-procedural rule, the standstill provision, does not comprise any substantial right with regard to departure, entry, access to or exercise of self-employment, or access to or exercise in the market in services or residence. ${ }^{184}$ Moreover, there is no right to family re-unification. ${ }^{185}$ In addition, Turkish nationals are not entitled to move in the Community freely, but benefit only from certain rights in a single Member State. ${ }^{186}$

I will now turn to the rights covered by Article 41(1) AP. Here we need another distinction: regular Turkish self-employed and others. The former category has the right of continued residence if they are already resident and a guarantee against expulsion that EU citizens and Turkish workers enjoy. ${ }^{187}$ The latter category involves the use of the standstill

\footnotetext{
182 Abatay and Sahin (n 2) paras 96-98.

183 Abatay and Sahin (n 2) para 99. This conclusion is also consistent with the spirit and purpose of association. Abatay and Sahin (n 2) para 100.

184 Savas (n 56) paras 64-65; Abatay and Sahin (n 2) para 62; Tum and Dari (n 122) paras 54, 52. See White (n 42) 220.

185 See Rogers and Scannel (n 6) 372.

186 Savas (n 56) para 59. See also Abatay and Sahin (n 2) para 64. There are also opposing views to this statement in the doctrine. See, for example, Can and Özen (n 6) 209. It should be borne in mind that Turkish nationals may have this right in accordance with the provisions of Council Directive 2003/109/EC of 25 November 2003 concerning the status of third-country nationals who are long-term residents ([2004] OJ L 16).

187 See Savas (n 56) para 65. Besides substantive guarantees, the guarantee against expulsion includes procedural ones. See Case C-136/03 Georg Dörr v Sicherheitsdirektion für das Bundesland Kärnten and Ibrahim Ünal v Sicherheitsdirektion für das Bundesland Vorarlberg [2005] ECR I-4759 para 69. Rogers and Scannel make a distinction: on the one hand, Turkish nationals who are in a regular position will have the right of continued residence and the corresponding protection against expulsion; on the other hand, other self-employed Turkish nationals only have the right not to be subject to any new restrictions. Rogers and Scannel (n 6) 377. Peers also argues that Article 41(1) should mean that self-employed Turks have a continued right of residence in a Member State if they are legally resident already. He also adds later that Turkish service providers and self-employed persons should enjoy the same protections as EU citizens as regards expulsion when considered in the light of Articles 13 and 14 of the Ankara Agreement. These refer to the freedom of establishment and to provide services provisions of the Founding Treaties. Peers (n 63) 39-40, 47. Sharpston sees it as a nuanced approach. E Sharpston, 'Different but (Almost) Equal - The Development of Free Movement Rights under EU Association, Co-operation and Accession Agreements' in M Hoskins and W Robinson (eds), A True European: Essays for Judge David Edward (Hart Publishing, Great Britain 2004) 242. See also T Candan, 'ATA'in Son Kararları Işığında Ortaklık İlişkisinde Yerleşme Hakkı ve Serbest Dolaşım' in B Akçay, S Kahraman and S Baykal (eds) Avrupa Birliği'nin Güncel Sorunları ve Gelişmele (Seçkin Yayıncılık, Ankara 2008) 353.
} 
clause against the introduction of new national restrictions with regard to the following areas:

- first admission (as a corollary to the freedom of establishment and to provide services (including all the substantive and/or procedural conditions)); ${ }^{188}$

- $\quad$ freedom of establishment (including access and exercise); ${ }^{189}$

- $\quad$ freedom to provide services (including access and exercise); ${ }^{190}$

- $\quad$ residence (as a corollary to the freedom of establishment and to provide services); ${ }^{191}$

- family re-unification (as a complement of the freedom of establishment and to provide services), ${ }^{192}$

- $\quad$ expulsion (since there will be no access or exercise of freedoms in the case of expulsion). ${ }^{193}$

bb. Internal situation

Situations that are wholly internal to a Member State are beyond the scope of Community law. Therefore, there should at least be one factor connecting an activity to any situations envisaged by Community law. ${ }^{194}$

To date, there is one example which can be found in the Abatay/Sahin case. According to the Court, 'although ... the right freely to provide services may be relied on by a provider as against the State in which he is established, those services must then be provided for persons established

\footnotetext{
188 Tum and Dari (n 122) paras 55, 58, 60-61, 63, 69. Compare with: Case C-235/99 The Queen $v$ Secretary of State for the Home Department, ex parte Eleanora Ivanova Kondova [2001] ECR I-5421 para 54; Case C-63/99 The Queen $v$ Secretary of State for the Home Department, ex parte Wieslaw Gloszczuk and Elzbieta Gloszczuk [2001] ECR I-6369 para 51; Case C-257/99 The Queen $v$ Secretary of State for the Home Department, ex parte Julius Barkoci and Marcel Malik [2001] ECR I-6557 para 54. For authors who believe first admission is within the scope of the standstill clause even before this case, see Ott (n 56) 457; C Calliess, 'The Immigration Policy of the European Union - Paving the Way to Fortress Europe?' (2004) Institut für Völkerrecht der Universität Göttingen, Abteilung Europarecht Göttinger Online-Beiträge zum Europarecht No 1, 12.

189 Savas (n 56) para 65; Abatay and Sahin (n 2) para 65; Tum and Dari (n 122) para 49.

190 Abatay and Sahin (n 2) paras 67, 111.

191 Savas (n 56) para 65; Abatay and Sahin (n 2) para 65; Tum and Dari (n 122) para 49.

192 As Rogers and Scannel rightly indicate, the ECJ refers to internal market case-law when it deals with association law, and family unity is fundamental to EC Treaty provisions. Therefore, Article 41(1) extends also to the right of family re-unification. Rogers and Scannel (n 6) 372.

193 See Rogers and Scannel (n 6) 377; Peers (n 63) 47.

194 See Saunders (n 127) para 11.
} 
in another Member State'. ${ }^{195}$ Consequently, a German transport company cannot rely on Article 41(1) AP where the recipient of the services is also established in Germany, since there is now a factor connecting its activity to Community law. ${ }^{196}$

\section{c. Temporal scope}

Temporal scope relates to when Member States have been prevented from introducing new restrictions in the areas covered by the standstill clauses. Article 41(1) AP precludes Member States from adopting new restrictive measures from the date of entry into force of the Additional Protocol in that Member State. ${ }^{197}$ This is 1 January 1973 for the original six Member States (Germany, France, Italy, the Netherlands, Belgium, and Luxembourg) and the States of the first enlargement (the United Kingdom, Ireland, and Denmark). For other States, one has to check their accession to the Community/Union.

C. Effects

Article 41(1) AP prevents the application of conflicting national rules. ${ }^{198}$ From the entry into force of the Additional Protocol, national measures which adversely affect the position of Turkish nationals with regard to the rights covered by this Article are considered to conflict with the standstill provision. ${ }^{199}$ Nonetheless, Article 41(1) AP does not replace the substantive rule that is inconsistent with it, but, as a quasi-procedural rule, refers to the rules of a Member State that were existent when it entered into force. ${ }^{200}$

I will now try to define how we came to this conclusion. In other words, I will illustrate the test for deciding whether Community or national rules or policies conflict with the standstill clause. The issue has two aspects: the first one relates to restriction and justification, while the second concerns the limits of the standstill clause.

\footnotetext{
195 Abatay and Sahin (n 2) para 107. See also Case C-384/93 Alpine Investments BV v Minister van Financiën [1995] ECR I-1141 para 30; Case C-60/00 Mary Carpenter v Secretary of State for the Home Department [2002] ECR I-6279 para 30.

196 Abatay and Sahin (n 2) para 108.

197 Savas (n 56) para 69; Abatay and Sahin (n 2) para 117.

198 Abatay and Sahin (n 2) para 59. Rogers and Scannel reveal that the benefit of this provision extends to both substantive and procedural provisions, as well as any policies or practices in existence at the relevant time. Rogers and Scannel (n 6) 358.

199 Abatay and Sahin (n 2) para 80. Compare with Case 48/75 Jean Noël Royer [1976] ECR 497 para 74.

200 Tum and Dari (n 122) para 55. See also Gümrükçü (n 133) 44.
} 
a. Restriction and justification

aa. General remarks

Article 41(1) AP will prevent the application of inconsistent rules of national law. ${ }^{201}$

Article 41(1) AP will have this effect, as long as, first, there is a restriction on freedom of establishment or to provide services and secondly, it is regarded as a new restriction. ${ }^{202}$ In order to assess whether there is a new restriction, the object or effect of the national measures will be considered. $^{203}$

The crucial question is how we interpret 'restriction'. The answer is hidden in the case-law of the Court. The ECJ, taking into account Article 14 of the Ankara Agreement together with the objectives of the association, established the rule that the principles enshrined in Articles 45 and 46 TEC (with exceptions relating to the exercise of official authority and on the grounds of public policy, public security and public health) and in the Articles related to the freedom to provide services 'must be extended, so far as possible, to Turkish nationals to eliminate restrictions on the freedom to provide services between the contracting parties'. ${ }^{204}$

The next step is to refer to internal market case-law in order to assess whether a national measure constitutes a restriction. ${ }^{205}$ In my view, the Court will cope with justification at this stage, while it deals with restriction, given that it cites the relevant treaty articles and the case-law regarding the interpretation of them. ${ }^{206}$ I believe that the Court will be ready to hear justifications based on public interest, public policy, public security and public health and to apply its proportionality test, because it refers to the restriction approach developed in relation to free movement rights. ${ }^{207}$

If the Court considers that there is a restriction, it is for the national courts to assess whether it is a new restriction which worsens the posi-

$201 \quad$ Abatay and Sahin (n 2) para 59.

202 Abatay and Sahin (n 2) para 110.

203 Savas (n 56) para 69; Tum and Dari (n 122) para 47.

204 Abatay and Sahin (n 2) para 112.

205 Abatay and Sahin (n 2) paras 110-111, 113-115; Tum and Dari (n 122) para 47; Soysal (n 123) paras 55-57.

206 Abatay and Sahin (n 2) para 111.

207 This has not come before the Court. However, in the Abatay/Sahin case, the Court referred to cases where the 'restriction' approach and justification on the grounds of public interest was at issue. Abatay and Sahin (n 2) para 111, where the Court cited, inter alia, Säger (n 143) para 14 when it answered the question whether there was a restriction in the main case. 
tion of Turkish nationals compared to the rules in existence on the date of entry into force of the Additional Protocol for that State. ${ }^{208}$

I would like to give two cases as examples of this test: the Abatay/ Sahin and Soysal cases.

ab. The Abatay/Sahin and Soysal cases

In the Abatay/Sahin case, the Court, citing its internal market caselaw, acknowledged that an administrative authorisation such as a work permit constitutes a restriction within the meaning of the freedom to provide services. ${ }^{209}$ Moreover, in this case, the application of national legislation raised further problems, as the issuance of work permits had been consistently refused. Firstly, the provider of the services had to pay additional costs, and secondly their capacity to provide services in the Member State in question was affected because of not being able to use their staff. ${ }^{210}$ Hence, legislation in the main proceedings requiring Turkish nationals to hold a work permit constituted a restriction on the right of natural and legal persons to provide services in a Member State. ${ }^{211}$

The Court added that a work permit 'does not appear to be an appropriate measure' when Turkish nationals are temporarily sent to a Member State to provide services there. ${ }^{212}$

The national court will determine whether this restriction is a new one which worsens the situation of Turkish nationals when compared to the rules in existence on the date of entry into force of the Additional Protocol for that State, which was 1 January 1973 for Germany. ${ }^{213}$

As a result, Article 41(1) precludes the introduction of work permits, as such permits were not required at the time of the entry into force of the Additional Protocol for that State. ${ }^{214}$ However, the national court will examine whether the situation of Turkish nationals is less favourable than that applicable at the time of the entry into force of the Additional Protocol. ${ }^{215}$

\footnotetext{
208 Savas (n 56) para 48; Abatay and Sahin (n 2) para 116.

209 Abatay and Sahin (n 2) para 111. See Case C-113/89 Rush Portuguesa Ld ${ }^{\underline{a}} v$ Office national d'immigration [1990] ECR I-1417 para 12; Säger (n 143) para 14; Case C-43/93 Raymond Vander Elst $v$ Office des Migrations Internationales [1994] ECR I-3803 para 15; Case C-355/98 Commission of the European Communities $v$ Kingdom of Belgium [2000] ECR I-1221 para 35.

210 Abatay and Sahin (n 2) para 114.

211 Abatay and Sahin (n 2) paras 113, 110.

212 Abatay and Sahin (n 2) para 115. See Rush Portuguesa (n 209) para 15; Vander Elst (n 209) para 21

213 Abatay and Sahin (n 2) para 116.

214 Abatay and Sahin (n 2) para 117.

215 Abatay and Sahin (n 2) para 117.
} 
In the Soysal case, the issue was the application of a visa requirement to Turkish lorry drivers who were engaged in the provision of services in Germany. ${ }^{216}$ Turkish nationals as such were not subject to a visa requirement before 1 January 1973. However, they had been required to have a visa in order to enter the territory of Germany since 1 July 1980 according to national law and from 1 January 2005 according to German legislation implementing EC Visa Regulation 539/2001. ${ }^{217}$

The Court first dealt with the question of whether there was a restriction and secondly, whether it was a new restriction. As regards the first question, the Commission asserted that a Schengen visa had certain advantages compared to the conditions that applied in Germany before 1 January 1973. Nevertheless, the Court declared that national legislation which makes the ability to provide services conditional on a visa is liable to interfere with the actual exercise of that freedom'. ${ }^{218}$ This is because of the additional and recurrent administrative and financial burdens required to obtain a visa and the fact that when the visa is denied, the exercise of the freedom is prevented. ${ }^{219}$

As regards the second question, the Court determined that national legislation has at least the effect of making the exercise of freedom to provide services subject to stricter conditions than the ones that existed on 1 January $1973 .^{220}$ Therefore, they constitute a new restriction within the meaning of Article 41(1) AP. ${ }^{221}$ With regard to the fact that German legislation was implementing Community regulations, the Court saw sufficient to refer to the primacy of international agreements concluded by the Community over provisions of secondary law which require such provisions to be interpreted, as far as possible, consistently with those agreements. ${ }^{222}$

\footnotetext{
216 Soysal (n 123) para 51.

217 Soysal (n 123) paras 51-53.

218 Soysal (n 123) para 55.

219 Soysal (n 123) para 55.

220 Soysal (n 123) para 56.
}

221 Soysal (n 123) para 57. In his Article written after the Savas case, Ott clearly stated that because of the visa requirement for Turkish citizens in certain Member States and the measures taken to achieve this end by the Community, the situation of Turkish citizens had worsened. He pointed out at this time that in this respect the standstill clauses could come into play. Ott (n 56). See also Karluk (n 28) 95, 112. In comparison, Baykal thought that asserting the visa requirement to be illegal as a result of the Savas judgement was controversial. Baykal (n 90). For a similar view, see Candan (n 187) 353. In the end, it is clear for now that visa requirements also fall within the scope of the standstill clause.

222 Soysal (n 123) paras 58-59. See Case C-61/94 Commission of the European Communities v Federal Republic of Germany [1996] ECR I-3989 para 52. The international agreements concluded by the Community have supremacy over secondary Community law and national law. Such a conclusion was drawn with regard to a regulation in the Opel Austria 
The result is that Article 41(1) AP precludes the introduction of a visa requirement for Turkish nationals, such as that in the main proceedings, since it was not in place before 1 January $1973 .{ }^{223}$

\section{b. Limits}

There are some limits to the effects of the standstill clause: abuse of rights, prohibition of favourable treatment, measures against disturbances and the equality principle.

As regards the abuse of rights, Community law entitles Member States to take measures 'to prevent individuals from improperly or fraudulently taking advantage of provisions of Community law'. ${ }^{224}$ This issue was at stake in the Tum/Dari judgement. The United Kingdom Government asserted that the applicants in the main proceedings, who were failed asylum seekers, should not be permitted to invoke Article 41(1) AP, since this would result in abuse or fraud. ${ }^{225}$ However, the ECJ examined the evidence before it and stated that the national court had expressly excluded any fraud or the protection of a legitimate national interest, such as public policy, public security or public health. ${ }^{226}$ Moreover, there was no evidence to show that the applicants had invoked the standstill clause with the sole aim of wrongfully benefiting from advantages provided for

case. (Case T-115/94 Opel Austria GmbH v Council of the European Union [1999] ECR II-39 para 122.) In addition to this, the Ankara Agreement and Additional Protocol are agreements which individuals can rely upon to challenge the legality of secondary legislation. See K Lenaerts and E De Smijter, 'The European Union as an Actor under International Law' (1999-2000) 19 Ybk Eur Law 106-107, 112-113; İ Göçmen, 'Böyle Buyurdu Divan: Uluslararası Anlaşmalar ve Bu Kapsamda 1947 Tarihli GATT ve DTÖ Anlaşması ve Eklerinin Topluluk Hukukunda Doğurduğu Etkiler' (2008) 57 Ankara Üniversitesi Hukuk Fakültesi Dergisi 276, 281-284. See also Gutmann in H Kabaalioğlu and R Gutman, Ortaklık Anlaşması'nda Standstill Hükmünün Getirdiği Hareketlilik (Iktisadi Kalkınma Vakfı Yayınlar1, İstanbul 2008) 11; Dienelt in Dienelt, Kabaalioğlu and Aksoy (n 169) 14. However, here the Court found it sufficient to disregard the issue by mentioning 'consistent interpretation'. One possible explanation is that standstill clauses are applicable against individual states and they freeze the rules of them when they entered into force in that Member State. As a result, what the Court did is a practical solution to the problem.

223 Soysal (n 123) para 62. See also Tum and Dari (n 122) para 47. Although this case raised no justification issues, in the future it is evident that Member States will continue to apply border controls. As Abdulkuddus states, these controls are needed by Member States due to national security issues and migration control. See Abdulkuddus in H Kabaalio lu, N Rogers, M Abdulkuddus and S Baykal, Avrupa Toplulukları Adalet Divan ve İngiltere Mahkemelerinin Türk Vatandaşlarının Ülkeye Giriş Koşullarına İlişkin Son Kararları (İktisadi Kalkınma Vakfı Yayınları, İstanbul 2008) 19. Hence, such measures of Member States may be brought before the Court and the latter will have to answer the question of whether these measures of the Member State concerned are justified.

224 Centros (n 146) para 24.

225 Tum and Dari (n 122) para 64.

226 Tum and Dari (n 122) para 65. 
by Community law'. ${ }^{227}$ The fact that, after failing with their applications as asylum seekers, the applicants requested to enter the United Kingdom for the purpose of exercising freedom of establishment cannot be considered in itself as constituting abuse or fraud. ${ }^{228}$ In addition to this, Article 41(1) AP is a general provision which does not restrict its scope in relation to refugees. ${ }^{229}$ Consequently, there was no abuse of rights. ${ }^{230}$

The prohibition of favourable treatment is governed by Article 59 AP. According to this Article, 'in the fields covered by this Protocol Turkey shall not receive more favourable treatment than that which Member States grant to one another pursuant to the Treaty establishing the Community'. The Court commented on this Article in the Soysal case. ${ }^{231}$ In relation to the visa requirement applied to Turkish lorry drivers, the Court mentioned that if the visa requirement were applied to European citizens but not Turkish nationals, this would be a situation where Turkish nationals received more favourable treatment than European citizens, which would be clearly contrary to Article 59 AP. ${ }^{232}$

Measures against disturbances are covered by Article 60 of the Additional Protocol. According to this Article, the Community or by its authorisation the Member State(s) may take protective measures in three situations: if there are serious disturbances in a sector of the economy of the Community or of one or more Member States; if these serious disturbances prejudice the external financial stability of one or more Member States; if difficulties arise which adversely affect the economic situation in a region of the Community. ${ }^{233}$ As the rules relating to workers of ACD 1/80 (and ACD 2/76) are also covered by the Additional Protocol, the standstill clauses thereof may not be applicable when the Community or the Member State(s) take such a measure.

\footnotetext{
227 Tum and Dari (n 122) para 66.

228 Tum and Dari (n 122) para 67.

229 Tum and Dari (n 122) para 68.

230 Tum and Dari (n 122) paras 65-68.

231 The Sahin case, which relates to Article 13 ACD 1/80, is also relevant here, since it clarified the relationship of Article 59 AP to the standstill clauses in association law. In this case, the Court stated that 'the adoption of new rules which apply in the same way both to Turkish nationals and to Community nationals is not inconsistent with any of the standstill clauses laid down in the fields covered by the EEC-Turkey Association'. Sahin (n 111) para 67.

232 Soysal (n 123) para 61. Compare with C-325/05 Ismail Derin v Landkreis DarmstadtDieburg [2007] ECR I-6495 paras 58 ff; Case C-349/06 Murat Polat v Stadt Rüsselsheim [2007] ECR I-8167 paras $18 \mathrm{ff}$.

233 The Association Council should be notified immediately of such measures and their content (art 60(2) Additional Protocol). In the choice of measures, preference shall be given to those which will least disturb the functioning of the Association and these measures shall not exceed what is strictly necessary to remedy the difficulties that have arisen (art 60(3) Additional Protocol). Consultations may take place in the Association Council on these measures (art 60(4) Additional Protocol).
} 
As regards equality, this principle may work as a safety net when the new restrictions of Member States are justified, because these new measures should at least be equal to the ones applied to EU citizens. One example, a pending case before the ECJ, may make this picture clear. ${ }^{234}$ The Netherlands has imposed increased rates for administrative fees for residence permits on Turkish nationals since 1994. According to the Commission, the standstill clauses in association law prevent Member States from adopting such measures which have the purpose or effect of making Turkish nationals' rights derived from association law subject to more stringent conditions. The Commission, therefore, states that these administrative fees infringe the standstill clauses. In addition, the Commission argues that in so far as Turkish nationals are liable to pay administrative fees for residence permits, pursuant to the equality principle, such fees may not be higher than those imposed on EU citizens.

It can be seen from the position of the Commission that the equality principle has a role to play in combination with the standstill provisions. However, the role will be defined by the judgement of the Court in this case.

\section{Conclusion}

The Additional Protocol entered into force on 1 January 1973 and the first case with regard to Article 41(1) AP, which contains the standstill clause relating to the freedom of establishment and to provide services, was brought before the Court of Justice in 1998, although it had been known since 1989 that the standstill provision relating to workers was directly effective. As a latecomer to association law, standstill provisions today offer opportunities to Turkish citizens which cannot be underestimated. One striking example is the judgement of the Court in the Soysal case, which clearly precludes Germany from applying visa requirements to certain Turkish nationals.

These developments encourage us to be optimistic about further advances for Turkish citizens. However, we should not overemphasise the power of standstill clauses. On the one hand, a standstill clause obliges a Member State not to adopt any new restrictions in particular areas covered by the clause, but on the other, Member States still have the ability to apply their own measures, though dated back to the time when the standstill clause entered into force. ${ }^{235}$ Another limitation of these clauses is the fact that they are applicable to a single Member State. Hence, the

\footnotetext{
234 Commission $v$ Netherlands (n 54).

235 See Rogers in Kabaalioğlu, Rogers, Abdulkuddus and Baykal (n 223) 15.
} 
situation will differ from one Member State to another with regard to the areas of application of the clauses.

The judgements of the Court shed light on determining the scope of the standstill clauses. However, there are, inter alia, two areas in need of clarification which have the potential to expand the effects of the standstill provisions. The first of these relates to the personal scope of 'services'. I believe that the Court will extend its approach in internal market case-law to association law and accept service recipients within the personal scope of Article 41(1) AP. The second area concerns the possibility of an equality clause in association law. Taken together with the standstill provisions and other matters falling within the scope of association, the equality principle might possibly take a central position in the future shape of association law.

Here, I would like to mention certain possible developments that are needed in order to make the gains of Turkish citizens real. Firstly, there should be serious work on the related arrangements of Member States which may fall under the standstill clauses. ${ }^{236}$ Secondly, based on the effects of the standstill clauses in the laws of Member States and the Community, the parties of the association should meet specifically to assess the issue and look for solutions, as Article 41(2) AP clearly provides for this. ${ }^{237}$ Thirdly, the Commission, the guardian of Community law, should be informed of the rules of Member States which are inconsistent with the standstill clauses. ${ }^{238}$ It will then be in the hands of the Commission whether to bring a case before the Court against the Member State(s). Lastly, petitions should also be addressed to the European Parliament, which may also refer the situation to the Commission. ${ }^{239}$

Though waiting at the front door of the EU in order to join the club, Turkey's membership seems unlikely in the near future. This is why association law still matters. Turkey should claim its rights born from association law while still remaining on course for membership.

236 See Gümrükçü (n 133) 45, 53-54.

237 See Baykal (n 90) 31-32; Candan (n 187) 360; Aksoy (n 169) 30.

238 See Guild (n 1) 94; Aksoy (n 169) 30.

239 See Guild (n 1) 94. 